\title{
The Impact of Government Expenditure on Economic Growth in Kenya: 1963-2008
}

\author{
James N. Maingi \\ Department of Economics, Kenyatta University, Kenya
}

Copyright $\bigcirc 2017$ by authors, all rights reserved. Authors agree that this article remains permanently open access under the terms of the Creative Commons Attribution License 4.0 International License

\begin{abstract}
The rapid growth in government expenditure in Kenya has caused concern among policy makers on the implication of such growth. Over the three decades, government expenditure in the country grew at a faster rate than the growth rate of GDP. Given this fiscal scenario, an explanation of this requires studying the impact of government expenditure on economic growth. The specific objectives of the study were to: investigate the relationship between the components of government expenditure and economic growth; examine the effects of components of government expenditure on GDP growth rate; analyze the effects of government expenditure reforms on economic growth; and to draw policy implications from the findings. The data used were government expenditure components that included expenditure on government investment, physical infrastructure, education, health care, public debt servicing, economic affairs, general administration and services, defense, public order and national security, and government consumption. Sources of data were Kenya government documents and international financial statistics publications. The study applied Vector Auto Regression estimation technique using the annual time series data for the period 1963 to 2008 to evaluate the impact of government expenditure on economic growth. The Johansen cointegration tests revealed a long-run relationship between GDP growth rate and the selected components of government expenditure. Further, the Granger- Causality test indicated bi-directional causality between GDP growth rate and components of government expenditure. The results of impulse response functions and variance decomposition revealed that government expenditure on investment, physical infrastructure, education, health care, public debt servicing, economic affairs, general administration and services, defense, public order and national security and government consumption have effect on economic growth. Furthermore, the study established that expenditure reforms of budget rationalization, expenditure downsizing, privatization and governance affect economic growth. The study concludes that the composition of government expenditure and public expenditure reforms matter for economic growth.
\end{abstract}

Keywords Economic Growth, GDP, Government Expenditure

\section{Introduction}

\subsection{Background of the Study}

The relationship between economic growth and government expenditure is an important subject of analysis (Barro, 1990; Easterly and Robelo, 1993; Barro and Sala-iMartin, 1992; and 1995). A central question is whether or not government expenditure increases the long run steady state growth rate of the economy. The general view is that government expenditure, notably on physical infrastructure and human capital, can be growth-enhancing although the source of financing of such expenditures can be growth-retarding (Landau, 1983; Devarajan, 1993; Cashin, 1995; Kneller, 1999). The growth retardation is experienced because of disincentive effects associated with taxation (Musgrave and Musgrave, 1989). Government expenditure may directly or indirectly increase total output through its interaction with the private sector. Lin (1994) examined some of the ways in which government expenditure can increase growth. These included the provision of public goods and infrastructure, social services and targeted intervention such as export subsidies.

The nature of the impact of government expenditure on growth depends on its form. According to Barro (1990), expenditure on investment and productive activities including state-owned production should contribute positively to growth, whereas government consumption expenditure is expected to be growth-retarding. However, in empirical studies, it is sometimes difficult to determine which particular items of public expenditure should be categorized as investment and which one as consumption.

Several analytical and empirical studies have focused on the traditional and new channels through which different types of government expenditure can affect growth (King 
and Robelo, 1990; Barro, 1990; Barro and Sala-i-Martin, 1992; and 1995; Bleaney et al, 2001). A direct effect relates to an increase in the economy's capital stock (physical or human) reflecting higher flows of government funds, especially when they are complementary to those privately financed. Government expenditure on education and health, for example, contribute to an increase in the stock of human capital. Similarly, to the extent that they trigger an accumulation of physical capital, most government expenditure on infrastructure falls in the category of having a direct impact on growth (Barro and Sala-I-Martin, 1992).

In addition, government expenditure can also contribute indirectly to economic growth by increasing the marginal productivity of both government and private supplied factors of production. Government expenditure on research and development, for example, provides higher productivity in the interaction between physical and human capital factors. Similarly, other components of government expenditure related to enforcement of property rights and maintenance of public order can exert a positive indirect effect on growth by contributing to better use of existing capital and labour assets (Trotman, 1997). In countries where crime and violence are endemic, increased government expenditure on security can lead to lower production costs by reducing the need to protect employees and physical assets, hence increasing worker productivity and stimulating private physical investments.

\subsection{Trends and Composition of Government Expenditure}

In order to explain the growth in the overall government expenditure, it is helpful to consider its breakdown by expenditure categories. The expenditure can be broadly classified in terms of purpose as recurrent and development expenditure. Recurrent expenditure refers to expenditure of recurrent expenses that are less discretionary and are made on ongoing programmes or activities. It constitutes of wages and salaries, administration, transfers payment, debt repayment and welfare services. Recurrent expenditure may affect economic growth through its effects on people's ability and willingness to work, save and invest. Development expenditure refers to expenditure that is generally more discretionary and is made on new programmes and activities that are yet to reach their final desired state of completion. It constitutes of investment in such schemes as construction of railways, roadways and communication systems, irrigation and power projects, which raise economic growth both directly and indirectly through encouragement of further private investment (Ag'enor, 2007).

Figure 1.1 shows the proportion of recurrent and development expenditure of the total government expenditure during the last four decades.

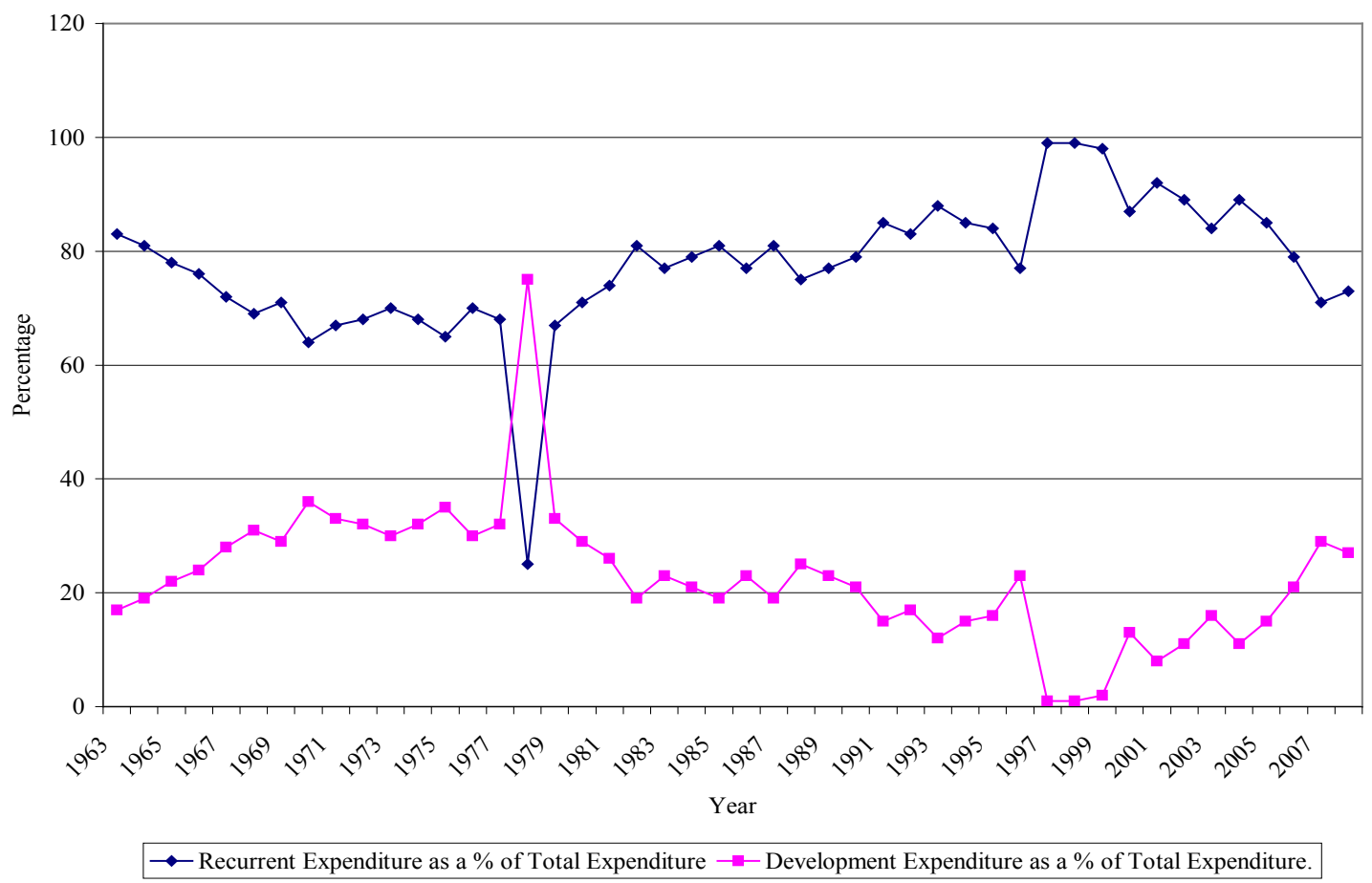

Source of data: Republic of Kenya Economic Survey and Statistical Abstract for various years

Figure 1.1. Trend of recurrent and development expenditure as a percentage of total expenditure (1963-2008) 
Figure 1.1 reveals that development expenditure has been lower than the recurrent expenditure in most of the years since independence. During the initial years of independence, the movements of recurrent and development expenditure were converging and these were the years Kenya recorded an impressive economic growth. During the initial period of independence, there was an upward trend in development expenditure, reaching 36 percent of total government expenditure in 1970 compared to 17 percent in 1963. This increase was attributed to increase in the construction costs (Republic of Kenya, 2003). During this period, the country was rebuilding and large amounts of money were spent on infrastructure and services. There was huge expenditure on electricity, roads, telecommunications and airport expansion. A lot of money was also spent on resettlement, nationalization and agricultural development. The proportion of development expenditure remained, on average 32 percent of total expenditure from 1972-1979, but began to decline thereafter and stagnated at about 19 percent of total government expenditure between 1982 -1996. A sharp decrease to less than 5 percent between 1999 and 2002 was witnessed. The declining trend in development expenditure over this period may have been attributed to austerity measures imposed on the government by the Bretton Woods institutions-either in form of World Bank's Structural Adjustment Programmes (SAPs) or through International Monetary Fund (IMF's) stabilization programmes. Since most recurrent expenditure is all but fixed (salaries and wages, interest on public debt and constitutional offices), the only leeway the government had in the wake of these austerity measures was its development budget (M'Amanja and Morrissey, 2005). Thus, most of the expenditure cuts had been affected through reductions in development expenditure, which in turn could have contributed to the declining trend of overall government expenditure, especially in the 1990s. This was a worrying trend because development expenditure was expected to provide the necessary infrastructure for private sector investment and growth, and therefore low budgetary allocation on this item meant that these services had been under-provided.

Finally, development expenditure showed an upward trend between 2003 and 2007. This was because of increased infrastructural expenditure in areas of roads, telecommunication, health and education, rehabilitation of airport in Nairobi, Mombasa and Kisumu.

Recurrent expenditure showed a declining trend from about 80 percent of total expenditure in 1963, to about 67 percent in 1971. This is because most expenditure in education and health were in the hands of the local authorities. From 1979 there was an upward trend in recurrent expenditure up to 88 percent of expenditure in 1993, which later dropped to 77 percent of government expenditure in 1996. This could be attributed to drought of 1980, compensation to Uganda government for the assets it lost to Kenya due to collapse of East African Community, increased expenditure on education since responsibility was transferred from local authority to central government. Education expenditure also increased due to expansion of educational physical facilities, expanded curricular and increased demand for teachers wage bill as a result of implementation of 8-4-4 system of education. The proportion of recurrent expenditure reached over 90 percent between 1997-2000, due to large expenditure incurred to finance the general election of 1997 and higher salary rewards to teachers and civil servants. Thereafter it declined, reaching below 71 percent in 2007. The decline was as a result of government refocusing its expenditure in favour of development, operations, maintenance and reduction of wage related expenditures.

The government expenditure can further be classified into various subcategories as follows: general administration services, health care, education and training, defense, economic affairs, infrastructure, public debts repayments and others.

Figure 1.2 indicates the paths of expenditures in selected subcategories of government expenditure during the study period, expressed as a percentage of total government expenditure. This breakdown into categories is helpful in understanding the composition of the long-run increase in government expenditure.

It is interesting to note that between 1963 and1982, virtually all components indicated an upward trend except public order and security expenditure. This is because of the increased cost of rehabilitating the Kenyan economy. From 1974 - 2002, there was marked increase in expenditure on such items as public debts and general administration. This could be attributed to excessive domestic borrowing in response to foreign aid freeze in 1991, and the first multiparty election of 1992, which was associated with high expenditure. Decline was witnessed in items such as health care, economic affairs, defense, infrastructure and public order and security, whereas that of education expenditure remained constant. Between 2002 and 2008, there was a drastic increase in all public expenditures except on public debts. This was as a result of: increase in wages of civil servants and teachers; expenditure on subsidies, grant and transfers; expenditure on acquisition of non-financial assets; expenditure on physical infrastructure; expenditure on two general elections (2002 and 2007) and the 2005 referendum on constitution; and expenditure on social sectors of education and health.

From the foregone trends, the determination of government expenditure may include factors such as fiscal stance and reforms such as downsizing and outsourcing, privatization, budget rationalization, political, social and economic factors. The Structural Adjustment Program (SAP) on macroeconomic variables introduced in the country in 1980s also heavily influenced government expenditure in Kenya. 


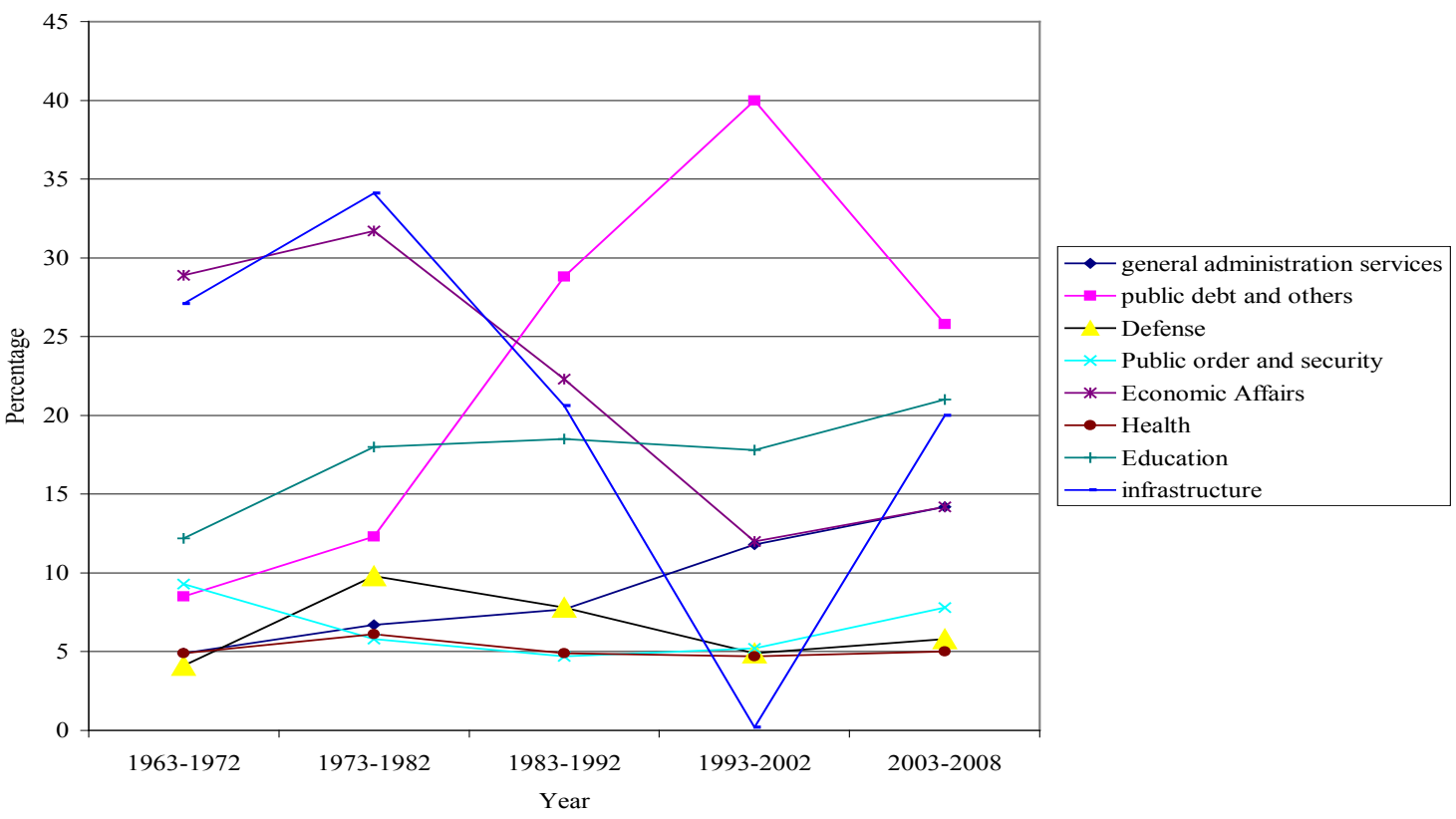

Source of data: Republic of Kenya Economic Survey and Statistical Abstract for various years

Figure 1.2. Government expenditure classification by sectors

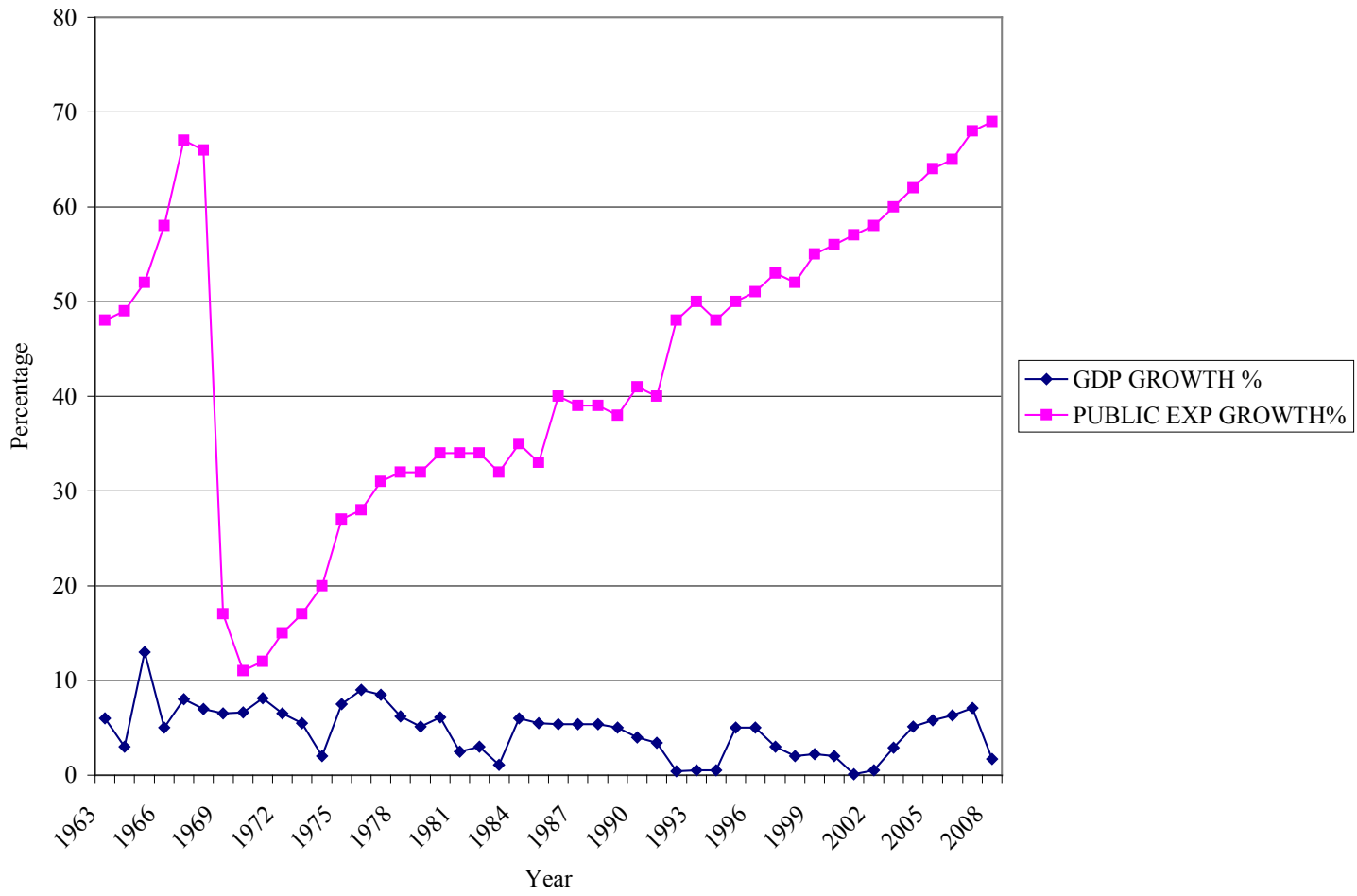

Source of Data: Republic of Kenya Economic Survey and Statistical Abstract for various years

Figure 1.3. Trends in GDP growth and government expenditure growth over the period 1963-2008

\subsection{Government Expenditure and Economic Growth in Kenya}

Trend in government expenditure growth and GDP in Kenya over the period of study is shown in figure 1.3.

Figure 1.3 shows that the trend in government expenditure growth increased steadily from 48 percent to
67 percent between 1963 and 1967, before declining drastically to 12 percent in 1971 (see appendix I table A1). Thereafter, the growth in public expenditure increased gradually up to 69 percent in 2008. During the same period, the rate of growth of the GDP was cyclical, depicting no clear pattern and responsiveness to the changes in government expenditure. Despite widespread fiscal 
stringency, average increase in government expenditure has tended to grow faster than that of GDP. The economic growth in Kenya can be categorized in four periods. The first period is between 1963 and 1972, when economic performance was impressive. The growth of GDP averaged 6.7 percent and compared favorably with some of the newly industrialized countries of East Asia (M'Amanja et $a l, 2005)$. This remarkable performance was attributed to increased development expenditure in areas of infrastructure such as roads, railways, electricity and also due to the expansion of recurrent expenditure on vital services such as education, health and housing.

The expansion in expenditure became more apparent beginning in early 1970s. The increases were generally due to the expansion of recurrent expenditure on vital services such as education, health and the need to maintain the real value of other services on account of rising inflationary pressure. Recurrent expenditure increased from a low Kenya pound 109 million in $1972 / 73$ to 3505 million in 1992/93 (Republic of Kenya, 2004). Notable expenditure jumps were occasioned by several factors: the 1973 and 1979 oil-crises, which led to increased inflation; the break of the East African Community which necessitated the setting up of independent corporations; the 1980 and 1984 drought that required massive food imports plus increased expenditure on internal security; and the coffee boom of 1976/77 (Wawire, 2006; Njuguna, 2009a). Overall, the 1980s witnessed rapidly expanding government expenditure. Among projects that benefited from increased outlays were the Moi Sports Complex that was built for the fourth all African games in 1987, the construction of Moi University at Eldoret, the Turkwel Hydro power station and the massive expansion of facilities at the public universities on account of the implementation of the 8-4-4 education system (Republic of Kenya, 2007). This marked an era of slow and persistent economic growth decline, with GDP growth rate falling from annual growth rate of 6.7 percent from 1963 to 1973 to 0.5 percent in 2002 .

There was a turnaround in the economic performance during the period 2003-2008, when the economic growth increased from 2.9 percent in 2003 to 7.1 percent in 2007. This was attributed to proper allocation of resources to areas that were critical to economic growth such as infrastructure and social sectors including education, health, economic affairs, defense, public order and national security (Republic of Kenya, 2009).

During this period, government expenditure for both recurrent and development increased substantially. This was as a result of increased wages and salaries due to the government commitment to improve the terms and working conditions of public servants. The main contributors of the rapid expansion of expenditure were the introduction of free primary education in $2002 / 03$, the shortfall of about 10 billion in foreign financed development spending, financing of referendum for constitution, expenditure on general election in 2007, change of government structure into a coalition government, introduction of subsidized secondary education, resettlement of victims of post-election violence, compensatory government expenditure due to international financial crisis, infrastructural development, large ministerial expenditure because of the bloated cabinet and general expenditure on the coalition government. Other major expenditure components included public debt servicing, use of goods and services, subsidies and grant and acquisition of non-financial assets (Republic of Kenya, 2008). Finally, there was a sudden fall in GDP growth rate in 2008. However, government expenditure growth dropped slightly.

\subsection{Government Expenditure Reforms in Kenya}

Since independence, various government expenditure reforms have been implemented. The reasons for the reforms were to raise and sustain the economic growth rate of the country. The public sector contributes to GDP growth rate through provision of government services such as education, health and administration, and productive activities in areas of agriculture, manufacturing, transport and communication and trade (Republic of Kenya, 1979). The government plays a leading role in determining the pattern of economic growth through public sector reforms, which determine directly how much of the country's resources to divert to its own use, and how those resources should be allocated in order to increase economic growth. The contribution of each sector to the growth rate of GDP in Kenya has been affected by the government expenditure reforms that have been undertaken by the government. The main government expenditure strategy has been restructuring overall expenditure by directing more resources to activities that promote faster economic growth. To achieve this goal, various policy reforms have been implemented, which include: rationalizing government expenditure, with more resources being channeled to development and recurrent non-wage operating and maintenance expenditure in order to stimulate economic growth (Republic of Kenya, 2002).

In the plan period 1974-1978, the policy target was to increase development expenditure by 9 percent in order to expand output. Total capital formation was expanded three times that of the preceding five years. These investments were in agriculture, forestry, manufacturing, electricity and government capital formation. In terms of allocation, priority was given to rapidly expanding education programme and economic and social services, while growth in expenditure on administration, new buildings and main trunk roads was restricted (Republic of Kenya, 1974).

During the planning periods $1979-1983,1984-1988$, 1989-1993 and 1997-2001, the government undertook rationalization of government expenditure, with more resources being channeled to development and recurrent 
non-wage operating and maintenance expenditure in order to stimulate economic growth (Republic of Kenya, 1997).

Sessional Paper No 1 of 1986 on Economic Management for Renewed Growth contained the Structural Adjustment Programmes suggested by World Bank and International Monetary Fund (Republic of Kenya, 1986). The central thrust of the policies was to rely on market forces to mobilize resources for economic growth and development, with the role of government increasingly confined to providing an effective regulatory framework and essential public infrastructure and social services. The changes in allocation of budget resources were implemented by government. The government spent proportionately more on immediately productive services. It also increased its outlay on infrastructure to promote smaller towns and rural centers to improve overhead facilities, including roads, power and water supplies. In agriculture, more money was channeled to research, extension services including tea and coffee planting programmes and other projects to raise agricultural production. The government spending on polytechnics and credit programmes to assist small scale industries in both rural and urban areas were also increased. These expenditures received the first allocation in the budgets that followed (Republic of Kenya, 1986). As a result, the share of formal education, health and other basic needs expenditure was reduced (Republic of Kenya, 1986).

The other major change in budget allocation involved a concerted effort to make all government outlays more efficient and productive through budget rationalization (Republic of Kenya, 1986). To achieve rationalization, the following measures were taken: projects with potentially high productivity were identified and their completion was advanced with an infusion of funds; projects with low potential benefits were identified and postponed or cancelled to free up funds for projects with higher returns; resources were shifted toward operation and maintenance expenditure of existing public facilities and away from investments in new projects; and new development projects were to be funded only if they were productive investment with very high priority (Republic of Kenya, 1986). The general approach then was that available resources for development budget were concentrated on few projects to shorten the construction or implementation period. At the same time, recurrent allocations were diverted to improve the utilization of existing capacity in order to raise productivity of public investments. The goal was to ensure that all government investments became productive as soon as possible through a programme of budget rationalization (Republic of Kenya, 1986).

In order to reduce the rate of growth of expenditure on salaries and allowances, several measures were adopted in 1990, which included the freezing of recruitments into job groups $A$ to $G$ and the ban on filling of posts that were vacant for more than six months (Republic of Kenya, 1994).

Sessional Paper No 1 of 1994 on Recovery and
Sustainable Development articulated various expenditure policies (Republic of Kenya, 1994). There was a re-allocation of budget resources towards the core functions of government. These included maintenance of law and order, the administration of justice, the provision of broad-based education and health services, the provision of economic infrastructure and the protection of the environment. To spur economic growth, the development expenditure and recurrent non-wage operating and maintenance expenditure were increased as a share of GDP. The budget rationalization measures aimed at maximizing the productivity of public expenditure. In particular, objective technical and economic criteria were to be applied to project selection, with priority given to projects in the areas of health, education, infrastructure and environment (Republic of Kenya, 1994).

In the plan period 2002-2008, Kenya's fiscal strategy aimed at increasing the level of economic activity by enhancing the role of private sector as the leading sector in wealth creation. The objectives were: to sustain reduction in the level of government expenditure as a percentage of GDP; to change the composition of government expenditure to focus more on efficient public investment and operations and maintenance in the long-run; and to strengthen the budgeting process. This was to be achieved by rationalizing allocations to recurrent expenditure, especially on wages, interest payments and transfer, while allowing development expenditure to grow (Republic of Kenya, 2002).

There has been increased development expenditure, especially that targeting government investment in core social expenditure in education and health. The expenditure strategy adopted in the Economic Recovery Strategy (ERS) document was to restructure overall expenditure by gradually reducing the level of recurrent expenditure. This was aimed at facilitating a rapid increase in development expenditure within a sustainable macroeconomic framework (Republic of Kenya, 2004).

In the Vision 2030, the government is targeting an economic growth rate of over 10 percent by 2030 (Republic of Kenya, 2007). To achieve this, the government has proposed the control of government expenditure to ensure that it does not lead to crowding out of private investments. The key element of the fiscal strategy includes containing growth of total expenditures while creating fiscal space through expenditure rationalization to shift resources from non-priority to priority areas, including expenditure on the flagship projects that are critical to achieving Vision 2030 (Republic of Kenya, 2007). In this context, the wage bill is expected to decline gradually to 6 percent, suggesting the need for civil service reforms that would facilitate higher remuneration for smaller and more efficient civil service. The increasing requirements for operation and maintenance for the expanded infrastructure has been catered for. The share of development expenditure in total 
outlays is to be increased from 18 percent in 2007 to 38 percent in 2012 and thereafter. Most of the increase in development expenditure is to benefit the priority sectors such as the infrastructure (expansion of road networks, energy and water supply capacities, and information and technology), agricultural sector and social sectors such as health and education. The country is to scale-up resources towards the above sectors in order to ensure efficiency and effectiveness in their use and management (Republic of Kenya, 2007).

Given the trends in the government expenditure and GDP growth rate, the government expenditure reforms that have taken place so far, and the aspirations of the vision 2030 , it is important that a study on the effects of government expenditure and government expenditure reforms on economic growth be carried out. This will unearth the necessary government expenditure reforms that are still needed in order to achieve the Vision 2030.

\section{The Statement of the Problem}

The causes of much of the variations in economic growth over time are not well understood. In particular, the effect of government expenditure on economic growth has not been explored exhaustively. Several studies have attempted to investigate the channels through which different types of government expenditure can affect growth (Landau, 1983; Diamond, 1984; Barro, 1990; Davarajan et al, 1993; Kweka, 1995; Colombier, 2000; Njuguna, 2009). From these studies, the effects of government expenditure on economic growth appear to be inconclusive. Despite this uncertainty, theory suggests that government expenditure has a positive effect on economic growth (Keynes, 1936; Solow-Swan, 1956; Musgrave and Musgrave, 1989; Barro, 1990; Barro and Salai-i-Martin, 1992, 1995).

In Kenya, economic growth has been fluctuating despite the government expenditure increasing over time. The Kenyan government spends substantial amounts of money annually on physical infrastructure, education, health care, economic services, public order and national security, defense and general administration. From theory, when there is an increase in government expenditure in these sectors, it is expected that the economy will exhibit a positive economic growth, but this does not seem to happen in the case of Kenya (See figure 1.3). This could be due to non growth-enhancing expenditures that crowd-out outlays that are meant to boost economic growth (Colombier, 2000). Therefore, the issue of which government expenditure can foster permanent movements in economic growth becomes important.

The Kenyan government has undertaken various budgetary rationalization and reforms aimed at curbing unproductive government expenditure, which has been rising over the years. Government expenditure has also been restructured to enhance economic growth by increasing development expenditures, especially those targeting public investments, such as those on education and health. However, despite the reforms, economic growth has not kept pace with government expenditure growth. Therefore, there is need to investigate the impact of government expenditure and its reform on economic growth. In particular, understanding the impact of the different components of government expenditure and reforms on economic growth is crucial to policy makers.

\section{Research Questions}

The study sought answers to the following questions

(i) What is the relationship between the components of government expenditure and economic growth in Kenya?

(ii) What are the effects of the components of government expenditure on economic growth?

(iii) What is the effect of government expenditure reforms on economic growth?

\section{Objectives of the Study}

The main objective of this study was to analyze the impact of government expenditure on economic growth in Kenya for the period 1963 to 2008 . The specific objectives were:

(i) To investigate the relationship between the components of government expenditure and economic growth in Kenya.

(ii) To examine the effects of the components of government expenditure on economic growth.

(iii) To analyze the effects of government expenditure reforms on economic growth.

\section{Literature Review}

\subsection{Introduction}

In this chapter, both theoretical and empirical literature on government expenditure and economic growth is reviewed. The first section reviews the theory and exposes the theoretical foundations that underlie the effects of government expenditure on economic growth. The theoretical representations of the models are described. The second section reviews studies carried out on the subject, and the final section deals with the critic of the literature.

\subsection{Theoretical Literature}

There are several theories advanced on government expenditure. The following is a brief discussion on each one of them.

\subsubsection{Wagner's Organic State Theory}

The German economist Adolf Wagner (1835-1917) 
advanced a law of rising public expenditure by analyzing trends in the growth of public expenditure and in the size of public sector in many countries of the world. This theory is primarily concerned with the explanation of the growth of the share of GNP taken up by the public sector. This theory, popularly known as Wagner's law, states that as per capita income grows, the relative size of the public sector will grow also. This is because the state would need to expand administration and law and order services; increased concern for distributional issues; and a greater need to control private monopolies and other forms of market failures. Thus, the state grows like an organism reflecting changes in the society and economy and making decisions on behalf (and to the benefit) of its citizens (Brown et.al, 1996).

The flaw in Wagner's theory is that it does not contain a well-articulated theory of public choice. The law assumes the problems of public choice by employing an organic theory of the state. Thus the state is assumed to behave as if it were an individual existing and making decision independently of the members of society. Expansion of public sector also cannot be explained in the absence of industrialization, and finally, the law concentrates upon a demand side explanation of government expenditure growth without considering the supply side explanations. In many ways, Wagner's law provides a good explanation of public sector growth. Its main limitation is that it concentrates solely on the demand for public sector services. What must determine the level is some interaction between demand and supply.

\subsubsection{Peacock and Wiseman's Political Constraint Model}

Analysis of the time path pattern of public expenditure by Professor A.T. Peacock and J. Wiseman (1890-1935) established the displacement effect. This model is based upon a political theory of government expenditure determination, namely that governments like to spend more money; that citizens do not like to pay more taxes; and that governments need to pay attention to the wishes of their citizens. The model assumes that there is some tolerable level of taxation that acts as a constraint on government behaviour. As the economy (and thus income) grows, tax revenue at constant rate would rise, thereby enabling government expenditure to grow in line with GNP (Peacock and Wiseman, 1961).

During period of social upheaval such as war, famine or some large scale social disaster, the gradual upward trend in government expenditure would be distorted (displaced upward). In order to finance the increase in government expenditure, the government may be forced to raise taxation level, a policy which would be regarded as acceptable to the electorate during period of crises. This is called the displacement effect (Peacock and Wiseman, 1961). Besides, there is also the inspection effect. This arises from people's keener awareness of social problems during the period of upheaval. The government, therefore, expands its scope of services to improve these conditions, since people's perception of tolerable levels of taxation does not return to its former level, the government is able to finance these higher levels of expenditure originating in the expanded scope of government and debt charges. The net result of these two effects is occasional short- term jumps in government expenditure within a rising long-term trend (Peacock and Wiseman, 1961).

The theory is very relevant to the Kenyan situation because the economy has experienced so many displacements in terms of tribal clashes, famine, and revenue boom like coffee boom of 1976/77. In all these, the government expenditure increased drastically without it falling in the subsequent periods (Republic of Kenya, 2003). The theory is not comprehensive since there are other periods where the government expenditure has gone up and yet there were no war or famine.

The flaw in Peacock and Wiseman's political constraint model is that if the situation after crises is not explored, the growth in government expenditure may change. It is also important to note that government finances its expenditure from internal and external borrowing, aid, income from sale of goods and services produced by government agencies and also from abroad. Thus taxation is not the only form of financing government expenditure (Brown et. $a l, 1996)$. The theory has also been criticized for giving insufficient weight to political influences on the level of public expenditure. Moreover, the theory does not isolate all relevant causes at work. Furthermore, the critics of this theory are based on answer to the question: What happens to expenditure in the post war period?. There is no long-run displacement effect in the case where civilian public expenditure in the post war period return to their original growth path or in the case where there is only a temporally increase in post war civilian public expenditure until the old trend line is reached. There is evidence that after deferred civilian public expenditure has taken place following the war, public outlays return to the pre-war level (Brunkhead and Miner, 1979).

\subsubsection{Endogenous Growth Theory}

The chief inventors of endogenous growth theory are Paul Romer and Robert Lucas (1990). This theory highlights the fact that if productivity is to increase, the labour force must continuously be provided with more resources. Resources in this case include physical capital, human capital and knowledge capital (technology). Therefore, growth is driven by accumulation of the factors of production while accumulation in turn is the result of investment in the private sector. This implies that the only way a government can affect economic growth, at least in the long-run, is via its impact on investment in capital, education and research and development. The approach makes improved education (and indeed any kind of training or research that adds to human knowledge in any country) the key to achieving economic growth. 
Faster economic growth is associated with a higher rate of investment by the private or government sector, a lower share in GDP of government consumption spending, higher school enrollment rates, and greater political stability. Unlike neo-classical growth theory, technical change is no longer based to chance, but can be fostered and promoted by appropriate policies. Moreover, as the foundation for innovation and entrepreneurship are secured, the probability of further technical change and associated economic growth occurring, rise significantly. Technical change is no longer regarded as unexplainable and due to chance as in neo-classical theory, but in endogenous theories becomes itself a variable which can be influenced by policy decisions and should now be included within production functions, alongside the conventional inputs of labour and capital. Government policies can affect economic growth rates by taxing consumption, subsidizing investment and research, and shifting resources from government consumption to government investment.

Reduction of growth in this models occurs when government expenditure deter investment by creating tax wedges beyond what is necessary to finance investments or taking away the incentives to save and accumulate capital (Folster and Henrokson, 1997).

\subsection{Empirical Literature}

Landau (1983) used panel data of 27 Less Developed Countries (LDCs) to investigate the relationship between government expenditure components and economic growth. The methodology used by the study was Ordinary Least Squares (OLS). The variable used was government expenditure, which was broadly categorized as productive and consumption expenditure.

The model used by the study was given as:

$$
\frac{\Delta Y}{Y}=\alpha\left(\frac{I}{Y}\right)+\beta\left(\frac{\Delta L}{L}\right)+\left(\frac{G}{Y}\right)
$$

where $\mathrm{Y}$ was the GDP, I was productive government expenditure, $\mathrm{G}$ was the consumption government expenditure, $\alpha$ was the marginal productivity of capital in non-governmental sector, $\beta$ was elasticity of the non-governmental output with respect to labour and $\mathrm{L}$ was labour input. Landau's model, measured the size of the government by the ratio of government expenditure to GDP.

The results were that consumption expenditure had a negative impact on economic growth, while productive expenditure had a positive effect on economic growth. In particular, the study found the following results: First, public investment on transport and communication was positively associated with economic growth. This finding was supported by the result of Canning and Fay (1995) on infrastructure and growth, which revealed a strong relationship between the physical stock of roads and growth. Secondly, general investment was positively correlated with growth. Finally, public enterprises investment was negatively correlated with private investment. The strength of the finding is that it offers moderate support for the view that infrastructure investment foster growth, but that public investment in general does not. The weakness of the study was that it did not conduct causality tests. The use of OLS was not backed by any economic theory.

Koori (1984) studied the existence and nature of the crowding effect in Kenya using Ordinary Least Squares and found that phenomenon growth in domestic deficit financing of government expenditure crowded out private borrowing. The study used the time-series data. Particularly the study pointed that the pattern of public sector investment expenditure completely crowded out the private investment in the manufacturing industry, electricity and water sectors. The study considered only one side of the government expenditure that is public investment. It did not consider public consumption. The main weakness of the study was failure to test for long-run relationship between the variables using cointegration analysis.

Landau (1985) using cross-section data for 104 countries, including 96 developing countries used panel data to analyze the effect of government expenditure on economic growth. The variables used were current expenditure and infrastructural expenditure. The study found that the big government measured by the share of expenditure in consumption reduced growth of per capita income. This method could not be used to separate short-run and long-run effects on government expenditure. The study concluded that total government expenditure, current expenditure and infrastructure had a dampening effect on growth.

Landau (1986) extended the earlier study using sixty five countries and related growth in per capita income to several set of independent variables that included; human and physical capital, structure of production, historical and political factors, resources, population and geo-climate, a measure of international economic conditions, and a three year lagged averages of the share of the government spending in GDP, which was disaggregated into education, defense, and transfer payments. By disaggregating government expenditure while holding other determinants of economic growth constant, it was found that government consumption had a negative and statistically significant influence on growth, whereas the influence of spending on education was positive but statistically insignificant. The results also showed that the influence of military expenditure net of the effect of taxation to finance it was essentially zero, as was the effect of transfers. Thus the earlier findings were re-affirmed (Landau, 1983). The methodology used was Generalized Least Squares (GLS), which may not be appropriate for time-series data in the present study.

Ram (1986) investigated the government size and 
economic growth using a cross-section and time-series data. The variables used were private investment, government expenditure and labour force growth rate. The study noted that a large government size was likely to be detrimental to efficiency and economic growth because: government operations were often conducted inefficiently; the regulatory process imposed excessive burdens and costs on economic system; and many government's fiscal and monetary policies tended to distort economic incentives and lower the productivity of the system. At the same time, the study highlighted that a large government size was likely to be a more powerful engine of economic development. This is due to various reasons such as: role of the government in harmonizing conflicts between private and social interests; prevention of exploitation of the country by foreigners; and securing an increase in productive investment and a socially optimal direction for growth and development. The study is relevant to the Kenyan case since in a developing economy, both the level and composition of government expenditure are important. The model was based on a mixed economy where both public and private sectors coexist, which is the case in Kenya.

\section{Research Methodology}

\subsection{Introduction}

The chapter presents the empirical model adopted for the study. The variables used in the study are defined. The data, the data sources and the methods used in data analysis are explained.

\subsection{Research Design}

This study aimed at establishing the effects of government expenditure on economic growth in Kenya. Quantitative data were used in the study to answer the research questions posed in chapter one. The study used data for the period 1963 to 2008 for the components of government expenditure, namely: government investment, physical infrastructure, government consumption, public debt servicing, general administration and services, defense, public order and national security, education and training, health care and economic affairs. The collected data were analyzed using (VAR) model after undergoing time-series property tests.

\subsection{Theoretical Framework}

This study used a modified version of Ram (1986) model based on endogenous growth theory. The model was chosen because it captured most of the government expenditure variables, which could easily be disaggregated into various sectors. In addition, the model showed clearly how the expenditure by government exercised an externality effect on output in the other sector (private). Furthermore, the model was able to show the intersectoral productivity differentials of the government expenditure. The endogenous growth theory formed a basis for empirical models of government expenditure and growth. This is because growth could arise when capital and labour are augmented by additional government input in the production function. This input provides the link between government expenditure and economic growth. The model was derived from private sector output $(D)$ and public sector output $(G)$, with capital $(K)$ and labour $(L)$ allocated between both sectors such that $K=K_{D}+K_{G}$ and $L=L_{D}+L_{G}$. To capture externalities associated with the public sector, $G$ entered the production function of the private sector $D$ :

$$
\begin{gathered}
D=D\left(K_{D}, L_{D}, G\right) \\
G=G\left(K_{G}, L_{G}\right)
\end{gathered}
$$

Assuming a constant productivity differential between labour in both sectors:

$$
\frac{G_{L}}{D_{L}}=\frac{G_{K}}{D_{K}}=(1+\delta)
$$

where $\delta>0$ implies lower productivity in the public sector (the reverse would be the case if $\delta<0$ ) and $\delta \neq 0$

Totally differentiating (3.1) and (3.2), given that national income $\mathrm{Y}=\mathrm{D}+\mathrm{G}$, gives

$d Y=D_{K} d K_{D}+G_{K} d K_{G}+D_{L} d L_{D}+G_{L} d L_{G}+D_{G} d G$

where $D_{K}$ and $G_{K}$ were marginal products of factor K in sector $\mathrm{D}$ and $\mathrm{G}$ respectively.

Similarly, $D_{L}$ and $G_{L}$ were marginal product of factor L. Further, DG was the marginal externality effect of public on private sector. From (3.3):

$$
G_{L}=(1+\delta) D_{L}
$$

Substituting (3.5) into (3.4) and rearranging:

$d Y=D_{K} d K_{D}+G_{K} d K_{G}+D_{L} d L_{D}+D_{L} d L_{G}+\delta D_{L} d L_{G}+D_{G} d G$

$d Y=D_{K} d K_{D}+G_{K} d K_{G}+D_{L}\left(d L_{D}+d L_{G}\right)+\delta D_{L} d L_{G}+D_{G} d G$

Using (3.5) then:

$$
d G=G_{K} d K_{G}+(1+\delta) D_{L} d L_{G}
$$

This implied:

$$
\frac{d G}{(1+\delta)}-\frac{G_{K}}{(1+\delta)} d K_{G}=D_{L} d L_{G}
$$

Substituting (3.7) into (3.6) and collecting terms: 


$$
\begin{aligned}
& d Y=D_{K} d K_{D}+G_{K} d K_{G}+D_{L}\left(d L_{D}+d L_{G}\right)+\delta\left[\frac{d G}{(1+\delta)}-\frac{G_{K}}{(1+\delta)} d K_{G}\right]+D_{G} d G \\
& d Y=D_{K} d K_{D}+G_{K} d K_{G}+D_{L} d L_{D}+D_{L} d L_{G}+\delta\left[\frac{d G}{(1+\delta)}-\frac{G_{K} d K_{G}}{(1+\delta)}\right]+D_{G} d G \\
& d Y=D_{K} d K_{D}+D_{L} d L_{D}+G_{K} d K_{G}+\left[\frac{d G}{(1+\delta)}-\frac{G_{K} d K_{G}}{(1+\delta)}\right]+\delta\left[\frac{d G}{(1+\delta)}-\frac{G_{K} d K_{G}}{(1+\delta)}\right]+D_{G} d G \\
& d Y=D_{K} d K_{D}+D_{L} d L_{D}+G_{K} d K_{G}+(1+\delta)\left[\frac{d G}{(1+\delta)}-\frac{G_{K} d K_{G}}{(1+\delta)}\right]+D_{G} d G \\
& d Y=D_{K} d K_{D}+D_{L} d L_{D}+G_{K} d K_{G}+d G-G_{K} d K_{G}+D_{G} d G \\
& d Y=D_{K} d K_{D}+D_{L} d L_{D}+\left(1+D_{G}\right) d G
\end{aligned}
$$

Assume the existence of a linear relationship between the marginal products of labour in each sector and the average output per unit of labour in the economy, that is $D_{L}=\left(\frac{Y}{L}\right)$

Letting $d K_{D}=I$ (gross investment), and substituting it into (3.8), then dividing through by $\mathrm{Y}$ gave:

$$
\begin{aligned}
& \frac{d Y}{Y}=\frac{D_{K} I}{Y}+\frac{D_{L} d L_{D}}{Y}+\frac{\left(1+D_{G}\right) d G}{Y} \\
& D_{L}=\frac{Y}{L} \\
& \frac{d Y}{Y}=D_{K} \frac{I}{Y}+\frac{\frac{Y}{L} d L_{D}}{L}+\frac{\left(1+D_{G}\right) d G}{Y} \\
& \frac{d Y}{Y}=D_{K} \frac{I}{Y}+\frac{d L_{D}}{L}+\frac{\left(1+D_{G}\right) d G}{Y}
\end{aligned}
$$

However, assuming that $D_{K}=\alpha,\left(1+D_{G}\right)=\lambda$ and including a coefficient for $\frac{d L_{D}}{Y}$ variable, the equation (3.9) became:

$$
\frac{d Y}{Y}=\alpha \frac{I}{Y}+\beta \frac{d L_{D}}{L}+\lambda \frac{d G}{Y}
$$

where equation (3.10) corresponded to Ram (1986) equation. Thus, equation (3.10) formed the basic model for regression estimation. The theoretical framework presented above predicts that economic growth $\left(\frac{d Y}{Y}\right)$ responds to the ratio of gross investment ( $I$ ) to GDP, growth of labour force $\frac{d L_{D}}{Y}$ and the ratio of change in government consumption to GDP $\left(\frac{d G}{Y}\right)$. The mechanisms through which government expenditure may affect economic growth are as follows. First, government investment in infrastructure is believed to have a direct effect on economic growth through increasing the economy's capital stock. The second channel is the externality effect of government spending that alters economic growth indirectly by raising the marginal productivity of privately supplied factors of production through expenditure on education, health and other services, which contribute to the accumulation of human capital. The third channel is government expenditure on goods and services that increases the aggregate demand in the economy. The fourth channel is intersectoral productivity differentials which makes some sectors to be more productive than others (Agenor, 2007).

\subsection{The Empirical Model and Estimation Technique}

In order to estimate the growth effects of the composition of government expenditure and take care of the intersectoral productivity differentials, equation (3.10) was modified by disaggregating investment into government investment and physical infrastructural. There was no time-series data on $\frac{d L_{D}}{Y}$. Therefore, the study used human capital development. This is because it captured the changing quality and stock of the labour force, and as such, was preferred to $\frac{d L_{D}}{Y}$. Government expenditure on education and health contribute to accumulation of human capital development. There were core functions of the government that could improve economic efficiency and thereby improve economic growth. These were protective and provision of a limited set of collective goods. The protective function included establishment of rule of law and property rights as exemplified by public order and national security. This 
helped to reduce the risks of criminal offences and social unrest so that safe and stable institutional environment for economic activities could be created. The involvement in producing goods for collective consumption included defense and general administration and services.

Government was also involved in direct production of goods and services in the economy. Further borrowing that was required to finance growing government expenditure could affect economic growth as well. To capture these influences, the study added expenditure on economic affairs and services, and the public debt servicing variables to Rams equation (3.10). The modified Rams model became:

$\frac{d Y}{Y}=\alpha_{0} \frac{I}{Y}+\alpha_{1} \frac{P I}{Y}+\alpha_{2} \frac{E D}{Y}+\alpha_{3} \frac{H T}{Y}+\alpha_{4} \frac{P D}{Y}+\alpha_{5} \frac{E A}{Y}+\alpha_{6} \frac{G A}{Y}$ $+\alpha_{7} \frac{D E}{Y}+\alpha_{8} \frac{N S}{Y}+\alpha_{9} \frac{d G}{Y}$

where: I is the government investment, PI is the physical infrastructure expenditure, ED is education expenditure, HT is health expenditure, PD is the debt servicing expenditure, EA is expenditure on economic affairs, GA is general administration and services expenditure, $\mathrm{DE}$ is the defense expenditure and NS is expenditure on the national security and public order by the government.

To capture the effects of government expenditure reforms on economic growth, a vector of dummy variables Dj was added to the above specification so that:

$\frac{d Y}{Y}=\alpha_{0} \frac{I}{Y}+\alpha_{1} \frac{P I}{Y}+\alpha_{2} \frac{E D}{Y}+\alpha_{3} \frac{H T}{Y}+\alpha_{4} \frac{P D}{Y}+\alpha_{5} \frac{E A}{Y}+\alpha_{6} \frac{G A}{Y}$ $+\alpha_{7} \frac{D E}{Y}+\alpha_{8} \frac{N S}{Y}+\alpha_{9} \frac{d G}{Y}+\alpha_{10} D j$

where $D j$ are dummy variables representing $j=1,2,3 \ldots \mathrm{N}$ government expenditure reforms.

Due to insufficient theories linking the above variables, the growth rate of GDP was not functionally explained by the explanatory variables on the right hand side of equation (3.12). Growth effects of government expenditure components could also emerge rather gradually overtime because they are complementary to private investments. These prompted the use of (VAR) method. This was because VAR model is a theory-free method used for the estimation of economic relationships (Sims, 1980 and Kosimbei, 2009).

VAR captured the evolution and the interdependence between multiple time-series, generalizing the univariate Auto Regressive (AR) models (Stock and Watson, 2001). All the variables in a VAR were treated symmetrically by including an equation explaining evolution of each variable based on its own lags and the lags of all the other variables in the model. The VAR model was preferred because all variables in the model were endogenous and each variable were expressed as a linear function of its own lagged values and the lagged values of all other variables in the system (Cheng and Lai, 1997). VAR was also used to test for causality between two or more variables.

\subsection{Definition and Measurements of Variables}

GDP growth rate $(\mathrm{g})$ : Is the average annual growth rate of real GDP. It was measured by change in GDP at constant prices as share of GDP.

Government investment expenditure (I): is the payment for acquiring land, buildings and other non-financial assets to be used for more than one year in the process of production, including transfers for capital assets. It was measured as the total capital expenditure including gross fixed capital formation and capital transfer as a share of GDP.

Physical infrastructure expenditure (PI): It is the government expenditure on capital overheads. It was measured as development expenditure on transportation, communication, electricity and waterways as a ratio of GDP.

Education expenditure (ED): Consists of all capital and current expenditure made by the central government for pre-primary through tertiary education. It was used as proxy for human capital development that affects the labour force. It was measured as the total expenditure on education (current and capital) as a ratio of GDP.

Health expenditure (HT): It consists of all expenditure made by the central government for hospitals, clinics, and public health affairs and services for medical, dental and paramedical practitioners; for medication, medical equipment and appliances; for applied research and experimental development. It was used as a proxy for human capital development that affects the labour force. It was measured as the total health expenditure (current and capital) as a ratio of GDP.

Public debt servicing (PD): It is the interest payments made by the central government for the use of all borrowed money both domestic and external. It was measured as the total interest payment for both domestic and external debts as a ratio of GDP.

Economic affairs expenditure (EA): It consists of all expenditure associated with the regulation and operation of business for economic development, redressing regional imbalances and creating employment opportunities. It was measured as the total expenditure on economic services (current and capital) as a ratio of GDP.

General administration and services expenditure (GA): It is the government expenditure in the office of the President, which includes administration police, provincial administration and criminal investigation department. I was measured as the total expenditure on general administration and services for both current and capital as a share of GDP.

Defense Expenditure (DE): This is the administration, supervision and operation of military defense affairs and forces: land sea, air and space defense force; administration, 
operation and support of civil defense forces. It was measured as the total defense expenditure (current and capital) as a ratio of GDP.

Public order and national security expenditure (NS): It represents the administration, management, supervision and operation of judicial services including the high court, the court of appeal, magistrate and Kadhi courts. It was measured as the total expenditure on public order and security for both current and capital as a share of GDP.

Government consumption expenditure $(\mathrm{Cg})$ : It is the current expenditure on purchases of goods and services at all levels of government. It encompasses purchases of materials, office supplies, fuel and lighting, travel services and payment of rent. It was measured by the recurrent government expenditure on labour costs and other goods and services as a ratio of GDP.

Budget rationalization (D1): It is the re-allocation of government expenditure from less productive to more productive projects of the government. It was equal to one during the years of budget rationalization and zero otherwise.

Expenditure downsizing and outsourcing (D2): It is the reduction in cost as a result of reducing the number of civil servants. It was a dummy variable that assumed the value of one in the years 1991, 1993, 1994 and 2002 when Kenyan government implemented the golden hand shake and comprehensive civil service reforms, and zero otherwise.

Privatization (D3): Is the sale of government enterprises to private individuals or companies. It was a dummy variable that assumed the value of one in 1991 onwards when the government started to carry out a comprehensive parastatal privatization and restructuring programme, and zero otherwise.

Governance (D4): It is the electoral and political processes. It was a dummy variable that assumed the value of one in 1992 when Kenya had the first multiparty election, in 2002 when there was a change in government, and in 2007 when coalition government was put into place, and zero otherwise.

\subsection{Time -Series Properties}

\subsubsection{Stationarity of Data}

The first step involved testing for stationarity of the series. This is a standard procedure performed to ensure that the series have a constant mean and variance, so that the resultant regression results would be meaningful (Tsay, 2001). Otherwise, if stationarity of the series is present and not checked, the presence of trend in the data series would mean that the regression results are spurious.

Two main methods for testing stationarity or the presence of unit roots that were applied are the Augmented
Dickey-Fuller (ADF) and Phillips-Perron (PP) tests (Perron, 1989). The ADF procedure attempts to retain the validity of the tests based on white-noise errors in the regression model by ensuring that the errors are indeed white-noise. On the other hand, (PP) procedure corrects for serial correlation through a non-parametric correction to the standard statistic (Stock, 1994).

\section{Empirical Findings}

\subsection{Introduction}

This chapter presents the findings of the study. First, the relationship between economic growth and components of government expenditure, namely government investment, expenditure on physical infrastructure, expenditure on health care, expenditure on education, public consumption, general administration and services, defense, public debt, economic affairs, public order and national security is explained. Second, the effects of the components of government expenditure on economic growth are estimated. Finally, the chapter explains the impact of budget rationalization, downsizing, outsourcing, privatization policies and governance on economic growth.

\subsection{Government Expenditure and Economic Growth}

The first objective of this study was to investigate the relationship between the components of government expenditure and economic growth. The study was expected to establish whether there was a short run or long run relationship between government expenditures on investment, physical infrastructure, education, health, public debt, national security, economic affairs, general administration, public consumption, defense and economic growth.

The data series were tested for stationarity using the Augmented Dicky Fuller (ADF) and Phillips-Perron (PP) tests. The results are presented in table 4.1.

The results of unit roots tests showed that GDP growth rate, government expenditure on investment, physical infrastructure, education, health, public debt servicing, public order and national security, economic affairs, general administration and services, public consumption and defense were stationary and integrated of order I (0). This suggested that there was a long-run relationship between variables (Engle and Granger, 1987).

Johansen test was then carried out to investigate whether there was more than a single cointegration relationship between economic growth and the government expenditure variables. The results of the Johansen tests of variables are reported in Table 4.2. 
Table 4.1. Unit roots tests results

\begin{tabular}{|c|c|c|c|c|c|c|}
\hline \multirow{3}{*}{\multicolumn{3}{|c|}{ Variables }} & \multicolumn{4}{|c|}{ Unit Root Test } \\
\hline & & & \multicolumn{2}{|c|}{ ADF test } & \multicolumn{2}{|c|}{ PP test } \\
\hline & & & & & & \\
\hline & & & t-statistic & Value $(5 \%)$ & t-statistic & Value $(5 \%)$ \\
\hline \multirow{2}{*}{$\begin{array}{l}\text { Public Consumption } \\
\text { Expenditure }\end{array}$} & \multirow[b]{2}{*}{ Levels } & Constant & $-3.43 *$ & -2.89 & $-4.61 * *$ & -2.89 \\
\hline & & $\begin{array}{l}\text { Constant and } \\
\text { Trend }\end{array}$ & -3.41 & -3.46 & $-4.59 * *$ & -3.45 \\
\hline \multirow[b]{2}{*}{ Defense Expenditure } & \multirow[b]{2}{*}{ Levels } & Constant & $-3.26^{*}$ & -2.89 & $-4.43 * *$ & -2.89 \\
\hline & & $\begin{array}{l}\text { Constant and } \\
\text { Trend }\end{array}$ & -3.30 & -3.46 & $-4.42 * *$ & -3.45 \\
\hline \multirow[b]{2}{*}{ Economic Affairs Expenditure } & \multirow[b]{2}{*}{ Levels } & Constant & $-3.38 *$ & -2.89 & $-4.51 * *$ & -2.89 \\
\hline & & $\begin{array}{l}\text { Constant and } \\
\text { Trend }\end{array}$ & $-3.68^{*}$ & -3.46 & $-4.68 * *$ & -3.45 \\
\hline \multirow[b]{2}{*}{ Education Expenditure } & \multirow[b]{2}{*}{ Levels } & Constant & $-3.54 * *$ & -2.89 & $-4.63 * *$ & -2.89 \\
\hline & & $\begin{array}{l}\text { Constant and } \\
\text { Trend } \\
\end{array}$ & $-3.50 *$ & -3.46 & $-4.62 * *$ & -3.45 \\
\hline \multirow[b]{2}{*}{ GDP Growth Rate } & \multirow[b]{2}{*}{ Levels } & Constant & $-3.93 * *$ & -2.89 & $-4.81 * *$ & -2.89 \\
\hline & & $\begin{array}{l}\text { Constant and } \\
\text { Trend } \\
\end{array}$ & $-3.95^{*}$ & -3.46 & $-4.81 * *$ & -3.45 \\
\hline \multirow{2}{*}{$\begin{array}{l}\text { General Administration and } \\
\text { Services Expenditure }\end{array}$} & \multirow[b]{2}{*}{ Levels } & Constant & $-3.54 * *$ & -2.89 & $-4.60 * *$ & -2.89 \\
\hline & & $\begin{array}{l}\text { Constant and } \\
\text { Trend }\end{array}$ & $-3.69 *$ & -3.46 & $-4.70 * *$ & -3.45 \\
\hline \multirow[b]{2}{*}{ Health Expenditure } & \multirow[b]{2}{*}{ Levels } & Constant & $-3.70 * *$ & -2.89 & $-4.66 * *$ & -2.89 \\
\hline & & $\begin{array}{l}\text { Constant and } \\
\text { Trend }\end{array}$ & -3.67 & -3.46 & $-4.63 * *$ & -3.45 \\
\hline \multirow{2}{*}{$\begin{array}{l}\text { Government Investment } \\
\text { Expenditure }\end{array}$} & \multirow[b]{2}{*}{ Levels } & Constant & $-3.45^{*}$ & -2.89 & $-4.48 * *$ & -2.89 \\
\hline & & $\begin{array}{l}\text { Constant and } \\
\text { Trend }\end{array}$ & $-3.65^{*}$ & -3.46 & $-4.57 * *$ & -3.45 \\
\hline \multirow{2}{*}{$\begin{array}{l}\text { Public Order and National } \\
\text { Security Expenditure }\end{array}$} & \multirow[b]{2}{*}{ Levels } & Constant & $-3.28 *$ & -2.89 & $-4.49 * *$ & -2.89 \\
\hline & & $\begin{array}{c}\text { Constant and } \\
\text { Trend } \\
\end{array}$ & -3.42 & -3.46 & $-4.58 * *$ & -3.45 \\
\hline \multirow[b]{2}{*}{ Public Debt Servicing } & \multirow[b]{2}{*}{ Levels } & Constant & $-3.28 *$ & -2.89 & $-4.43 * *$ & -2.89 \\
\hline & & $\begin{array}{l}\text { Constant and } \\
\text { Trend }\end{array}$ & -3.35 & -3.46 & $-4.49 * *$ & -3.45 \\
\hline \multirow{2}{*}{$\begin{array}{l}\text { Physical Infrastructure } \\
\text { Expenditure }\end{array}$} & \multirow[b]{2}{*}{ Levels } & Constant & -2.75 & -2.89 & $-3.84 * *$ & -2.89 \\
\hline & & $\begin{array}{l}\text { Constant and } \\
\text { Trend }\end{array}$ & -3.28 & -3.46 & $-4.16 * *$ & -3.45 \\
\hline & $*(* *)$ & $\mathrm{s}$ rejection of th & esis at 5 & ignificant le & & \\
\hline
\end{tabular}

Source: Constructed from the Study Data

Table 4.2. The Johansen cointegration test

\begin{tabular}{|c|c|c|c|c|}
\hline \multicolumn{2}{|c|}{$\begin{array}{c}\text { Series: Government consumption, defense, economic affairs, education, health, GDP growth, general administration, public order and national } \\
\text { security, public debt, government investment, physical infrastructure }\end{array}$} \\
\hline \multicolumn{5}{|c|}{ Lags interval: 1 to 4} \\
\hline Eigen value & $\begin{array}{c}\text { Likelihood } \\
\text { Ratio }\end{array}$ & $\begin{array}{c}5 \text { Percent } \\
\text { Critical Value }\end{array}$ & $\begin{array}{c}1 \text { Percent } \\
\text { Critical Value }\end{array}$ & $\begin{array}{c}\text { Hypothesized } \\
\text { No. of CE(s) }\end{array}$ \\
\hline 0.964855 & $1308.531^{* *}$ & 233.13 & 247.18 & None \\
\hline 0.950206 & $1044.018^{* *}$ & 233.13 & 247.18 & At most 1 \\
\hline 0.933814 & $807.0290^{* *}$ & 192.89 & 205.95 & At most 2 \\
\hline 0.893952 & $592.5218^{* *}$ & 156.00 & 168.36 & At most 3 \\
\hline 0.816512 & $415.2566^{* *}$ & 124.24 & 133.57 & At most 4 \\
\hline 0.781352 & $281.3038^{* *}$ & 94.15 & 103.18 & At most 5 \\
\hline 0.526459 & $161.2007^{* *}$ & 68.52 & 76.07 & At most 6 \\
\hline 0.430102 & $102.1469^{* *}$ & 47.21 & 54.46 & At most 7 \\
\hline 0.360701 & $57.72540^{* *}$ & 29.68 & 35.65 & At most 8 \\
\hline 0.209380 & $22.38209^{* *}$ & 15.41 & 20.04 & At most 9 \\
\hline 0.047228 & $3.822033^{*}$ & 3.76 & 6.65 & At most 10 \\
\hline
\end{tabular}


In the Johansen procedure, the likelihood ratio (LR) test is used to test the significance of estimates of Eigen values. The results in Table 4.2 showed the existence of a cointegrating relationship between GDP growth rate, government investment, physical infrastructure, public consumption, defense, economic affairs, education, general administration, health, national security and public debt. The LR test indicated eleven cointegrating equations at 5 percent level of significance. This meant that the variables had a long-run relationship, which could not necessarily hold in the short-run (Enders, 1995). The evidence of cointegration also ruled out the possibility of spurious correlation. Moreover, the cointegration tests results presented in table 4.2 revealed that the variables in their level form had a long-run relationship and hence the model estimation could be conducted in the standard Sims-type VAR at levels (Enders, 1995).

Nevertheless, the cointegration result did not point the direction of the long-run relationship between variables. Since there was evidence of cointegration, then this implied that there must be Granger-causality from GDP growth rate to government expenditure, or vice versa, or both. Therefore, the next step was to carry out Granger-causality tests. It is a technique for searching the direction of causation between variables after the existence of cointegration (Kalyoncu and Yucel, 2006).

Granger causality was used to determine whether one time series was useful in forecasting another (Enders, 1995). Prior to the application of the test, the study had to determine the appropriate VAR model. A VAR model with minimum Akaike and Schwarz information criteria and an optimum lag of one appeared to be a better model specification. Hence, the Granger - causality test was performed on the model.

Rejection of the null hypothesis implied that a temporal change in categories of government expenditure led to permanent change in GDP growth rate. On the other hand, failing to reject the null hypothesis of no causality meant that GDP growth rate was not directly explained by the categories of government expenditure. The results of the Granger-causality tests are presented in table 4.3.

Table 4.3. Granger causality tests

\begin{tabular}{|c|c|c|c|c|}
\hline Null Hypothesis & F-Statistic & Lags & Probability & Conclusion \\
\hline $\begin{array}{c}\text { GDP growth does not Granger - Cause government expenditure on } \\
\text { investment }\end{array}$ & $2.89^{*}$ & 10 & 0.034 & \multirow{2}{*}{ Bi-directional } \\
\hline $\begin{array}{l}\text { Government expenditure on investment does not Granger - Cause } \\
\text { GDP growth }\end{array}$ & $23.81 * *$ & 2 & 0.000 & \\
\hline $\begin{array}{l}\text { GDP growth does not Granger - Cause expenditure on physical } \\
\text { infrastructure }\end{array}$ & $6.57 * *$ & 9 & 0.001 & \multirow{2}{*}{ Bi-directional } \\
\hline $\begin{array}{l}\text { Expenditure on physical infrastructure does not Granger - Cause } \\
\text { GDP growth }\end{array}$ & $8.16^{* *}$ & 3 & 0.000 & \\
\hline $\begin{array}{l}\text { GDP growth does not Granger - Cause expenditure on government } \\
\text { consumption expenditure }\end{array}$ & 3.56 & 1 & 0.067 & \multirow{2}{*}{$\begin{array}{l}\text { Uni-directional causality } \\
\text { running from Public } \\
\text { consumption to GDP } \\
\text { growth }\end{array}$} \\
\hline $\begin{array}{l}\text { Expenditure on government consumption does not Granger - Cause } \\
\text { GDP growth }\end{array}$ & $16.67 * *$ & 2 & 0.003 & \\
\hline GDP growth does not Granger - Cause expenditure on defense & $6.34 * *$ & 4 & 0.001 & \multirow{2}{*}{ Bi-directional } \\
\hline Expenditure on defense does not Granger - Cause GDP growth & $4.89 * *$ & 4 & 0.001 & \\
\hline $\begin{array}{l}\text { GDP growth does not Granger - Cause expenditure on economic } \\
\text { affairs }\end{array}$ & $3.16^{* *}$ & 10 & 0.006 & \multirow{2}{*}{ Bi-directional } \\
\hline $\begin{array}{l}\begin{array}{l}\text { Expenditure on economic affairs does not Granger - Cause GDP } \\
\text { growth }\end{array} \\
\end{array}$ & $4.39 * *$ & 5 & 0.001 & \\
\hline GDP growth does not Granger - Cause expenditure on education & $3.01 *$ & 5 & 0.024 & \multirow{2}{*}{ Bi-directional } \\
\hline Expenditure on education does not Granger - Cause GDP growth & $6.06^{* *}$ & 5 & 0.001 & \\
\hline $\begin{array}{c}\text { GDP growth does not Granger - Cause expenditure on general } \\
\text { administration and services }\end{array}$ & 2.93 & 10 & 0.056 & \multirow{2}{*}{$\begin{array}{l}\text { Uni-directional causality } \\
\text { running from General } \\
\text { administration and services } \\
\text { to GDP growth }\end{array}$} \\
\hline $\begin{array}{c}\text { Expenditure on general administration and services does not } \\
\text { Granger - Cause GDP growth }\end{array}$ & $3.18^{*}$ & 2 & 0.029 & \\
\hline GDP growth does not Granger - Cause expenditure on heath care & $3.35^{*}$ & 5 & 0.034 & \multirow{2}{*}{ Bi-directional } \\
\hline Expenditure on health care does not Granger - Cause GDP growth & $31.19^{*}$ & 10 & 0.019 & \\
\hline $\begin{array}{l}\text { GDP growth does not Granger - Cause expenditure on public order } \\
\text { and national security }\end{array}$ & $6.16^{* *}$ & 6 & 0.001 & \multirow{2}{*}{ Bi-directional } \\
\hline $\begin{array}{l}\text { Expenditure on public order and national security does not Granger } \\
\text { - Cause GDP growth }\end{array}$ & $12.61 * *$ & 10 & 0.000 & \\
\hline $\begin{array}{l}\text { GDP growth does not Granger - Cause expenditure on public debt } \\
\text { servicing }\end{array}$ & 8.97 & 14 & 0.376 & \multirow{2}{*}{$\begin{array}{l}\text { Uni-directional causality } \\
\text { running from Public debt } \\
\text { servicing to GDP growth }\end{array}$} \\
\hline $\begin{array}{l}\text { Expenditure on public debt servicing does not Granger - Cause GDP } \\
\text { growth }\end{array}$ & $3.98 * *$ & 14 & 0.000 & \\
\hline
\end{tabular}

Source: Constructed from the Study Data 
The Granger causality test results revealed that there was bidirectional causality between government expenditure on defense, economic affairs, education, health care, public order and national security, government investment, physical infrastructure and economic growth. This means that these set of variables predicted each other and hence could be on either side of the equation, (either as dependent or as an independent variable).

The variables that had a unidirectional causality included: government expenditure on consumption, general administration and services, and public debt servicing. This implies that only one variable could explain the other. In this case, they were required to be on the right hand side of the equation as independent variables.

The Granger causality tests revealed important information on the relationship between the variables of interest in this study. Government expenditure on investment, physical infrastructure, consumption, defense, economic affairs, education, general administration and services, public order and national security, health care and public debt predicts economic growth.

These findings confirm the results of Variance Decomposition Analysis (VDA), given that there was bidirectional causality between government expenditure on defense, economic affairs, education, health care, public order and national security, government investment, physical infrastructure and economic growth.

In a nutshell, there was a feedback effect between government expenditure components and GDP growth rate, which supported the Wagner's hypothesis that states that increase in GDP causes growth in the government expenditure, and the Keynesian hypothesis that states that increase in government expenditure causes GDP to increase. This suggests that allocation of government resources should be designed carefully in order to spur economic growth of the country.

\subsection{Effects of Government Expenditure on Economic Growth}

The second objective of the study was to examine the effects of the various components of government expenditure on economic growth. This was done by the estimation of the Structural Vector Auto Regression (SVAR) model and the subsequent use of impulse responses and variance decomposition analysis.

The VAR results presented in table A 6 in appendix IV were not interpreted like ordinary regression equations because they were not derived from structural equations (Enders, 1995). They were used for the generation of both the impulse response functions and for conducting the variance decomposition analysis, which depicted the effect of various components of government expenditure on economic growth.

The impulse response analysis traced the effects of one standard deviation shock to the innovation on current and future values of all the endogenous variables of the system. A shock to the $\mathrm{j}^{\text {th }}$ variable affected the same variable and was also transmitted to all other endogenous variables in the system through the dynamic structure of the VAR (Enders, 1995).

The ordering of variables used in this study was based on the relationship presented in equation (3.12) in chapter three. This ordering was also consistent with the variance decomposition analysis postulation that the variation to two shocks were more pronounced in the initial periods of the shock, and the influence reduced with the lags as the percentage variation of the other variables in the model increased. The impulse response of each expenditure component to a one standard deviation positive shock was generated over a thirty year period with ordering as government expenditure on; investment, physical infrastructure, education, health care, public debt servicing, economic affairs, general administration and services, defense, public order and national security, government consumption and dummy variables for budget rationalization, expenditure downsizing and outsourcing, privatization and governance.

The plots and impulse responses that follow summarize the results of the shock evaluation, indicating the responses of each variable over the 30 years horizon to one standard deviation positive shock to each of the eleven variables and four dummies in the VAR equation.

\section{(a) The Impact of Government Investment Expenditure} on GDP Growth Rate.

The impact of one standard deviation shock to government investment expenditure on GDP growth rate is shown in figure 4.1.

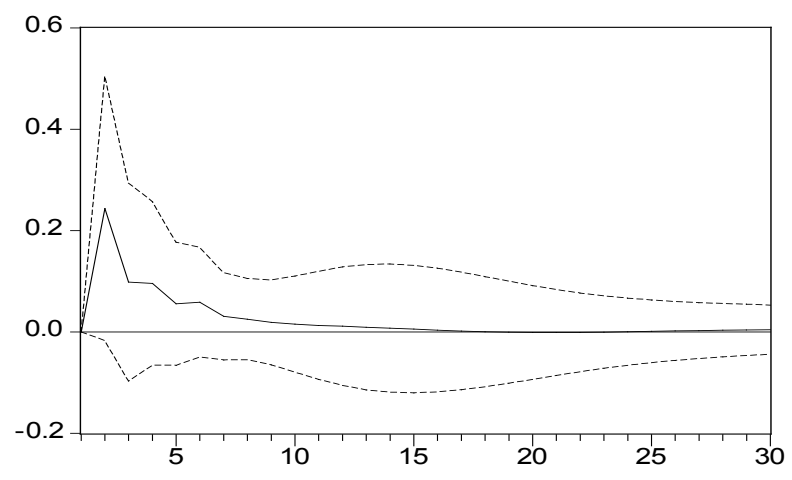

Source: Constructed from the Study Data

Figure 4.1. Impact of government investment on GDP growth rate

The response to one standard deviation to government investment expenditure resulted in a stable time path, which declined to zero with respect to economic growth as shown in figure 4.1. This effect lasted for sixteen years on the positive territory before fizzling out. The evidence on the relationship between government investment and economic growth remained inconclusive. Knight, Loayza and Villanueva (1993) and Nelson and Singh (1994) found 
that the level of government investment had a significant effect on economic growth during 1980s, while Khan and Kumar (1997) and Peter (2003) found government investment less effective on growth compared with private investment. Milbourne, Otto and Voss (2003) found evidence of a positive correlation between public investment and economic growth.

The reasons for the increase in GDP growth was because government expenditure on buildings, plant, machinery and equipment helped to increase the productivity of the inputs used by private sector. By increasing aggregate demand, public investment could have also stimulated private investment through the accelerator effect. The increase of what was also due to increase in aggregate demand through investment.

The decline could be due to the increased fiscal deficit or the crowding out of private capital formation by reducing credit available to the private sector or by raising interest rates.

(b) The Impact of Government Expenditure on Physical Infrastructure on GDP Growth Rate.

The impact of one standard deviation shock to physical infrastructure expenditure on GDP growth rate is shown in figure 4.2 .

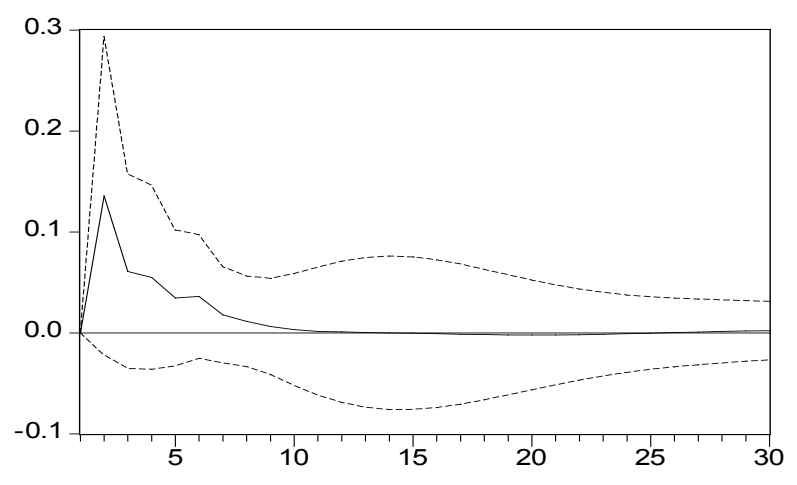

Source: Constructed from the Study Data

Figure 4.2. Impact of physical infrastructure expenditure on GDP growth rate

The response to one standard deviation to government infrastructural expenditure resulted in a stable time path, which declined to zero with respect to economic growth as shown in figure 4.2. The effect of a one standard deviation shock on physical infrastructure investment on economic growth lasted for twelve years on the positive territory, and then remained at the equilibrium in the long-run. This positive effect between infrastructure and economic growth finds support in studies by Aschauer (1989) and Easterly and Robelo (1993).

Additional expenditure on infrastructure in such areas as roads, railways, ports, communication, water and electricity could have contributed to economic growth by increasing the productivity of inputs in the private sector. High government expenditure on transport and communication and energy created an enabling environment for businesses to strive through reduced cost of production.

\section{(c) The Impact of Government Expenditure on Education on GDP Growth Rate.}

The impact of one standard deviation shock to education expenditure on GDP growth rate is shown in figure 4.3.

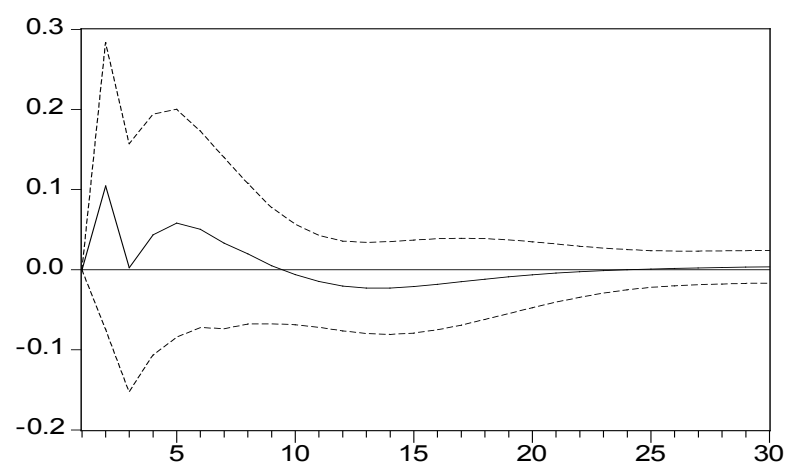

Source: Constructed from the Study Data

Figure 4.3. Impact of expenditure on education on GDP growth rate

Government expenditure on education improved the economic growth initially for nine years, before dampening it to the negative side for another 13 years. The response to one standard deviation to education expenditure resulted in a stable time path, which declined to zero with respect to economic growth. The effect lasted for twenty two years before fizzling out.

This phenomenon could be attributed to the increased marginal productivity of privately supplied factors of production. This could have occurred due to the provision of free primary and secondary education, expansion of the universities and middle level colleges, and bursary given to the needy students. Provision of free basic education and creation of subsidy schemes created positive externalities and raised the steady state rate of economic growth. However, there was a decline in its positive effect possibly due to the fact that the rate of unemployment is very high in Kenya, and therefore, there was no room for the majority of graduates in the Kenyan labour market. Further, government investment on building of schools, colleges and universities were expenditure on the core functions, and therefore were expected to have a positive effect on the economy. The slight negative effect in the long-run could be because funds meant for the development of the education sector had not been properly utilized and in most cases embezzled, thus precipitating the incessant strike by academic staff union of the university and national union of teachers.

The results differ from conclusion drawn by previous studies (Landau, 1986; Barro, 1995, 1999; and Devarajan, 1996). These earlier studies indicated that the association between education expenditure and economic growth was negative. 
(d) The Impact of Health Care Expenditure on GDP Growth Rate.

The impact of one standard deviation shock to health care expenditure on GDP growth rate is shown in figure 4.4.

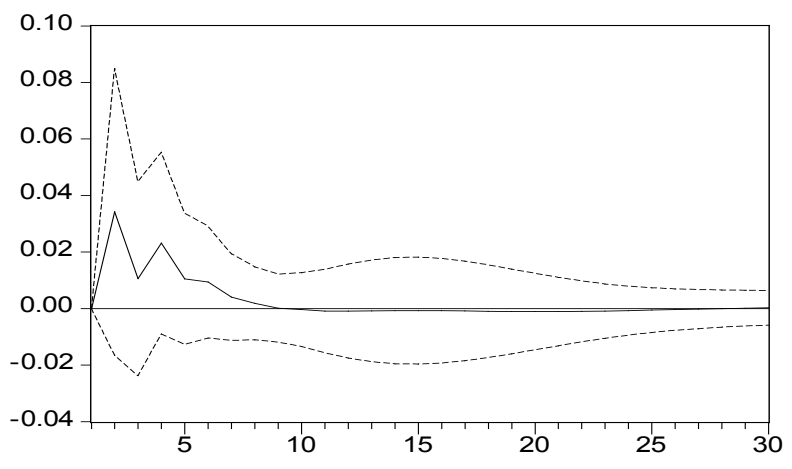

Source: Constructed from the Study Data

Figure 4.4. Impact of health care expenditure on GDP growth

The response to one standard deviation innovation to expenditure on health resulted in a stable time path that declined to zero with respect to economic growth as shown in figure 4.4. The positive effect lasted for nine years after which it fizzled out. The evidence of positive effect agrees with the results obtained by Diamond (1989).

This phenomenon could be owed to the fact that health expenditure by the government raise the health status and productivity of the people, thereby promoting economic growth. The increased expectation of a longer life could affect the inter-temporal discount rate and therefore savings. Increased health expenditure could increase the participation of women in the labour market, and affect fertility, which has effect on demographic transition and therefore on the economy. Further, government investments on buildings of hospitals represent expenditure on the core functions and therefore are expected to have a positive effect on the economy.

(e) The Impact of Public Debt Servicing Expenditure on GDP Growth Rate.

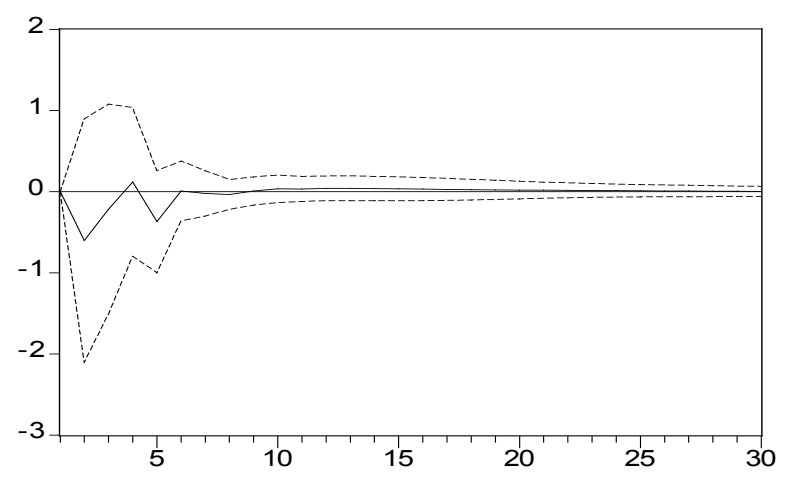

Source: Constructed from the Study Data

Figure 4.5. Impact of public debt servicing expenditure on GDP growth rate
The impact of one standard deviation shock to public debt servicing expenditure on GDP growth rate is shown in figure 4.5.

The response to one standard deviation innovation to public debt result in a stable time path that last for only seven years before reducing to zero. Its long-run impact on economic growth was nil. The evidence of negative effect of public debt on economic growth is in support of what Ranjan (2008) found in Pakistan. The sources of negative effect of public debt on economic growth are four fold: the resources used to service the public debt could have crowded out government investment in areas where complementarities existed between public and private capital outlays and this could have contributed to reduced private investment; high debt ratio could have led domestic agents to transfer funds abroad instead of saving domestically because of the fear of future tax liabilities to service the debt could; high debt burden might have discouraged foreign direct investment by increasing the likelihood that the government could resort to the imposition of restriction on external payments. Finally, firms could have held a large stock of foreign currency liability and as a result they were vulnerable to exchange rate fluctuations. The increase in risk of default could have made the domestic banks to tighten credit restrictions that depressed domestic investment.

(f) The Impact of Expenditure on Economic Affairs on GDP Growth Rate.

The impact of one standard deviation shock to economic affairs expenditure on GDP growth rate is shown in figure 4.6.

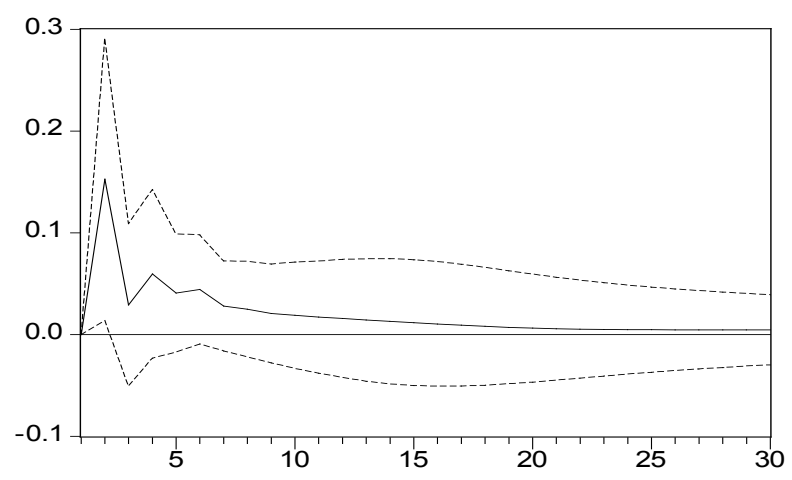

Source: Constructed from the Study Data

Figure 4.6. Impact of expenditure on economic affairs on GDP growth rate

The government expenditure on economic affairs exhibits a positive short-run impact on the GDP growth rate that takes about fifteen years to translate fully into a permanent shift in the GDP growth rate. This result is supported by Romer (1990), who found a positive relationship between government expenditure on economic affairs and economic growth. Nevertheless, when 
considering the impact in the long-run growth, it is zero. The reason for the positive effect could be because economic affairs provides a direct provision of productive activities through its expenditure in areas of agriculture, manufacturing, trade, mining, fisheries, forestry, tourism and constructions.

The findings of the study supports the finding of the study Njuguna (2009a) which noted that sectors such as trade, tourism and manufacturing are very critical areas of a nation's development and therefore the allocations to these sectors could make significant contribution to the economy if the resources are channeled to the right areas of development.

(g) The Impact of General Administration and Services Expenditure on GDP Growth Rate

The impact of one standard deviation shock to general administration and services expenditure on GDP growth rate is shown in figure 4.7.

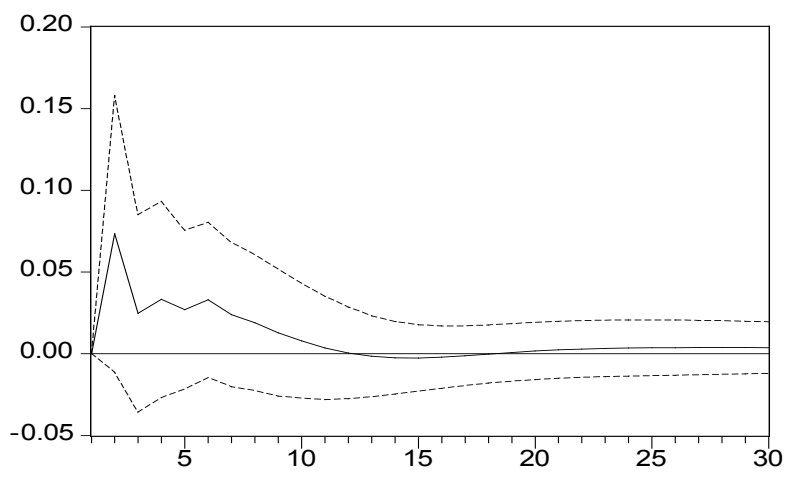

Source: Constructed from the Study Data

Figure 4.7. Impact of general administration and services expenditure on GDP growth rate

The response to one standard deviation to general administration expenditure result in a stable time path, which declines to zero with respect to economic growth as shown in figure 4.7. The effect of a one standard deviation shock on general administration on economic growth lasted for twelve years on the positive territory. This is in contrast with the findings of Ranjan (2008), who found a negative effect of general administration expenditure on growth.

General administration encompasses all expenditures that are of recurrent in nature. These are expenditures channeled to pay staff, buy office supplies, personnel management, purchase equity and transfer to households, public enterprises and the rest of the world. The positive effect could be attributed to the increased government expenditure on capital and transfer to households and enterprises, which act as a productive input and also help to increase the after -tax private return on capital. Transfers generated positive externalities that raised marginal product of private capital. Although a typical theoretical result is that for a given tax rate, economic growth is adversely affected by an increase in redistribution through public transfer, the result for this study is consistent with Barro (1989), Sal-i-Martin (1992) and Cashin (1995). Further, general administration could have led to an improvement in the efficiency in the markets for goods and services, factor markets and asset markets. Asset markets help to mobilize resources for investment. The negative effect could be as a result of increased government expenditure on establishment of inefficient public corporations, recruitment and promotion of staff in government owned institutions, increased salaries, wages and allowances for teachers and members of parliament, expansion of number of ministries and expenses on the coalition government.

(h) The Impact of Government Expenditure on Defense on GDP Growth Rate.

The impact of one standard deviation shock to defense expenditure on GDP growth rate is shown in figure 4.8.

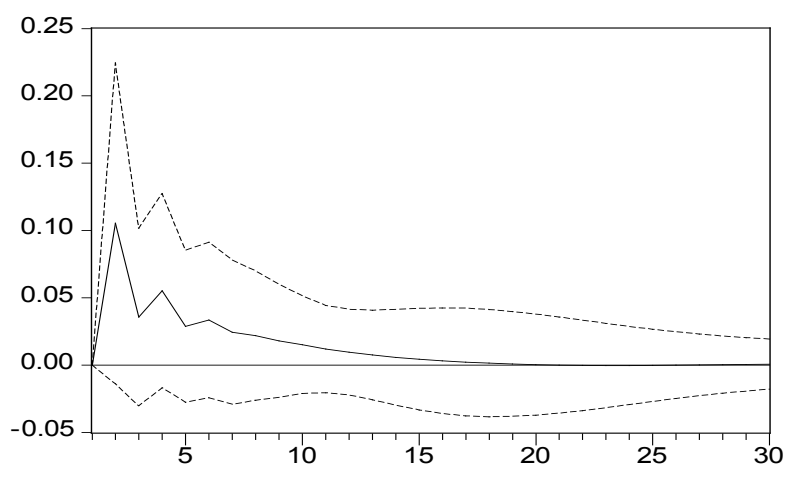

Source: Constructed from the Study Data

Figure 4.8. Impact of expenditure on defense on GDP growth rate

As shown in figure 4.8, it would take eighteen years for the effect on economic growth due to fizzle out if a one standard deviation shock on defense expenditure is affected. The effect is positive in the short run but in the long run it has no effect. In the existing literature, this effect has sometimes been reported as positive and significant for example by Benoit (1978); and Frideriksen and Loony (1982). At the same time, other studies have found it to be negative for example Bils and Klenow (1998); and Knight et al, (1996), while in yet other studies, effect of defense expenditure on GDP growth has been found to be neutral by for example Ram, (1986). The attributes of this phenomenon could be due to improved security within the economy thereby increasing economic activities such as tourism, and private investment.

\section{(i) The Impact of Public Order and National Security Expenditure on GDP Growth Rate.}

The impact of one standard deviation shock to public order and national security expenditure on GDP growth rate is shown in figure 4.9. 


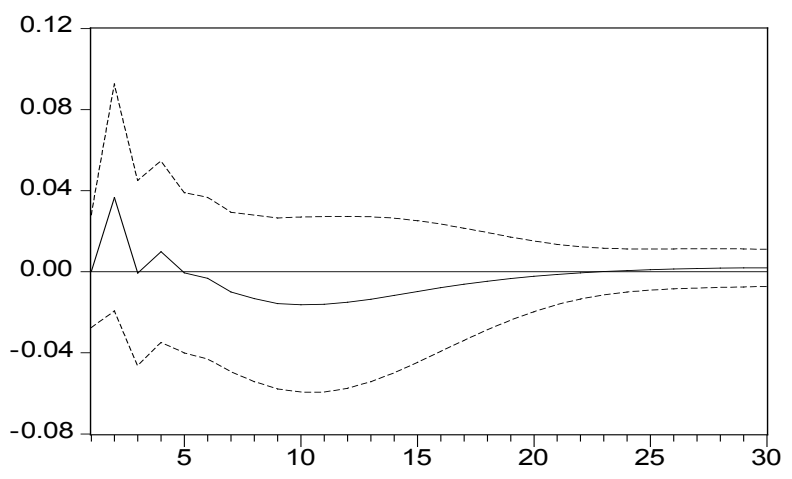

Source: Constructed from the Study Data

Figure 4.9. Impact of public order and national security on GDP growth rate

The response to one standard deviation innovation in public order and national security and public order resulted in a stable time path, which declined to zero with respect to economic growth as shown in figure 4.8. The effect of one standard deviation shock on national security on GDP growth rate took twenty two years to fizzle out. The effect was initially on the positive side for a period of five years, and then moved to negative territory for seventeen years before moving to the equilibrium. This suggests that national security has a mixed effect on GDP growth rate and the effect is felt for a long in the economy. This result is in support of Romer (1990), who found a negative relationship between this variable and economic growth.

There is no existing literature of the positive effect and therefore this study makes an important contribution to the existing literature in this area. The positive effect could be attributed to the increased competition in the economy due to increased protection and enforcement of government legal structure. The government spending more on the rule of law helped to improve the rights ownership of possessions and property as well as basic human rights to life and the right not to be kidnapped and enslaved. As a result, there was an improvement in the efficiency in the markets for goods and services, factor markets and asset markets. Asset markets helped to mobilize resources for investment. However, this turned into negative effect perhaps due to loss of confidence in the local courts by the public. As a result, the competition was curtailed and there was inefficiency in the above mentioned markets, which may have led to the decline in economic growth.

\section{(j) The Impact of Government Consumption Expenditure} on GDP Growth Rate.

Figure 4.10 shows the impact of a one standard deviation shock on the government consumption expenditure on GDP growth rate.

The response of economic growth to one standard deviation to government consumption expenditure resulted in a stable time path, which declined to zero. The results show that a one standard deviation shock on government consumption has a mixed effect on GDP growth rate that lasted for fifteen years.

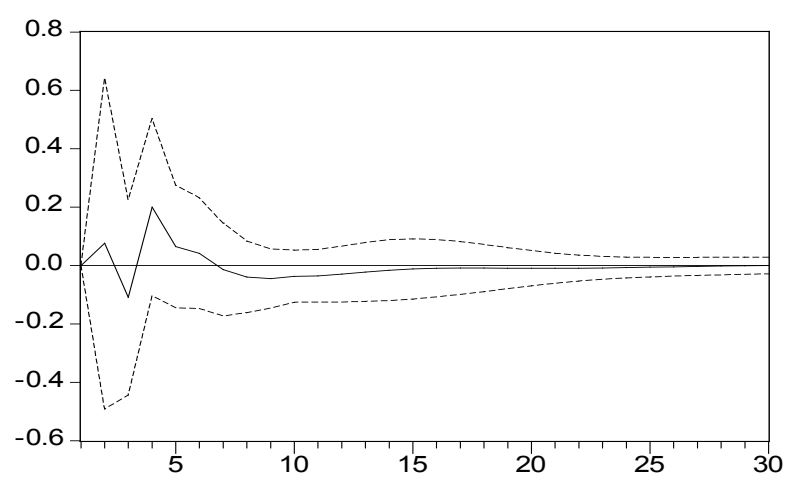

Source: Constructed from the Study Data

Figure 4.10. Impact of government consumption expenditure on GDP growth rate

In the short-run, government consumption expenditure has a positive effect on economic growth but in the long-run its effect was negative. This suggests that government consumption expenditure had a mixed effect on economic growth both in the short-run and in the long-run. In the existing literature, the effect of government consumption expenditure has produced mixed results for various studies. Barro (1997) found that government consumption expenditure measured as a proportion of GDP was negatively correlated with GDP growth. Devarajan, Swaroop and Zou (1996) in contrast found a positive relationship between GDP growth and government consumption expenditure. Caselli, Esquivel and Lefort (1996) also found a positive effect on growth of government expenditure as a share of output. Easterly, Loayza and Montiel (1997) found no significant effect of the share of government consumption expenditure on GDP on economic growth in Latin America.

The positive effect could be as a result of increase in aggregate demand through the multiplier effect. The negative effect could have resulted from the crowding out effect due to a fall in disposable income of the households. Financing government consumption expenditure is done through taxes or by borrowing. Hence, increased taxes lower disposable income for households and private consumption may fall accordingly. Government consumption expenditure could also have a crowding-out effect on private sector by causing positive effect on interest rates, which in turn could decrease private investment.

In summary, impulse responses traced out the responses of current and future values of each of the variables to a one unit increase in the current value of one of the VAR errors, assuming that this error returned to zero in subsequent periods, and that all other errors were equal to zero. These estimated impulse responses showed patterns of persistent common variation. The effect of the shock in government expenditure components was realized for a period of 
between ten and fifteen years. This means that government expenditure components have long-run impact on economic growth in Kenya.

\subsection{The Effect of Government Expenditure Reforms on Economic Growth}

The fourth objective of this study was to analyze the impact of government expenditure reforms on economic growth. To attain this objective, the dummies for budget rationalization, expenditure downsizing and outsourcing, privatization and governance were included in the VAR model estimation. The impulse responses and variance decomposition for the given dummies were analyzed and interpreted.

\section{(a) The Impact of Budget Rationalization on GDP} Growth Rate.

Budget rationalization was a dummy representing the reallocation of government expenditure from less productive to more productive projects of the government. It assumed the value of one during the years of budget rationalization and zero otherwise. The impact of one standard deviation shock to policy on budget rationalization on economic growth is presented in figure 4.11 .

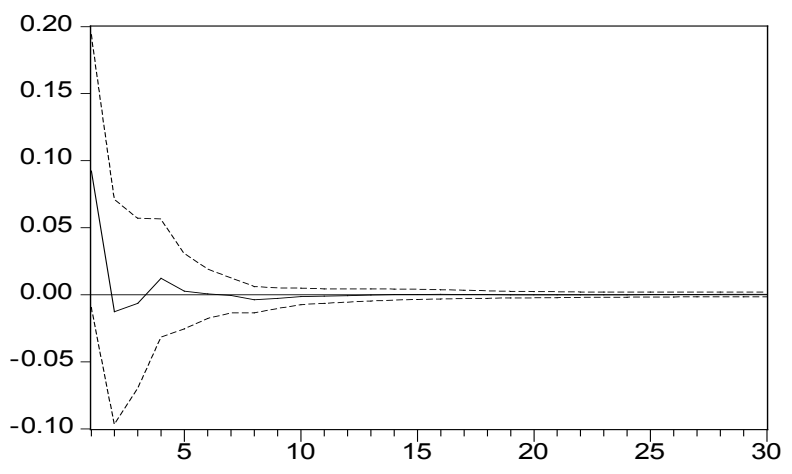

Source: Constructed from the Study Data

Figure 4.11. Impact of budget rationalizing on GDP growth rate

A shock on budget rationalization had a stable time path as far as its effect on economic growth was concerned. It had an instantaneous positive effect that declined to zero within a period of one year and then moved along the equilibrium after five years. The budget rationalization policy adopted during various years helped to increase the productivity of public expenditure. This is because it helped to re-allocate resources towards the core functions of the government. These are maintenance of law and order, the administration of justice, the provision of broad-based education and health, the provision of economic infrastructure and the protection of the environment. It also helped to shift resources from non-productive expenditure to development and recurrent non-wage operating and maintenance expenditure, which appear to have helped to spur the economic growth. Further, it helped to enhance the role of private sector as the leading sector in wealth creation by changing the composition of government expenditure. Finally, it helped to achieve efficiency in the public sector. Efficiency in resource use in the public sector is important as it helps in reducing government expenditure that are not related to the economic growth and increase on those that increase growth.

\section{(b) The Impact of Expenditure Downsizing and Outsourcing on GDP Growth Rate.}

Expenditure downsizing and outsourcing was a dummy representing reduction in costs as a result of reducing the number of civil servants. It assumed the value of one in the years 1991, 1993, 1994 and 2002 when the government implemented the golden hand shake and comprehensive civil reforms, and zero otherwise. The impact of one standard deviation shock to policy on downsizing and outsourcing on economic growth is presented in figure 4.12 .

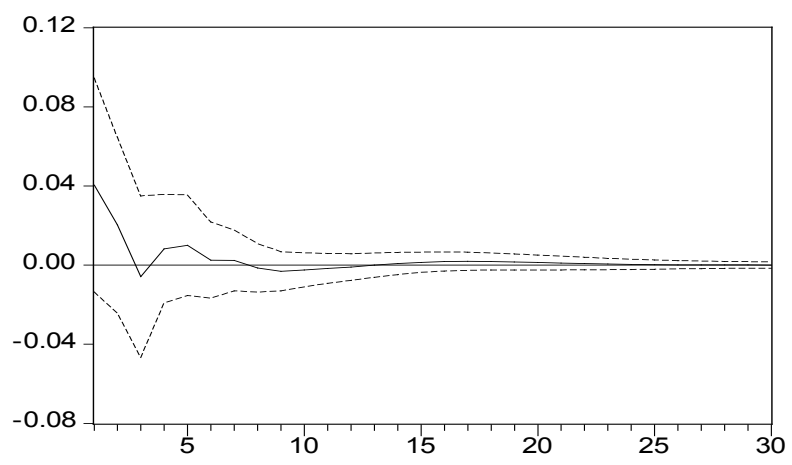

Source: Constructed from the Study Data

Figure 4.12. Impact of expenditure downsizing and outsourcing on GDP growth rate

The effect of one standard deviation shock on expenditure downsizing and outsourcing on economic growth took eight years to fizzle out. The effect was initially an instantaneous positive before declining to negative and then to the positive side and finally moving along the equilibrium in the long-run. The source of the positive effect could have been diversion of resources from unproductive expenditure on wages and salaries, to a productive expenditure in form of infrastructure or education.

\section{(c) The Impact of Privatization on GDP Growth Rate.}

Privatization was a dummy taking the value of one from 1991 onwards when the government started carrying out comprehensive privatization of the parastatals and restructuring programme, and zero otherwise. The impact of a one standard deviation shock to policy on privatization on economic growth is presented in figure 4.13. 


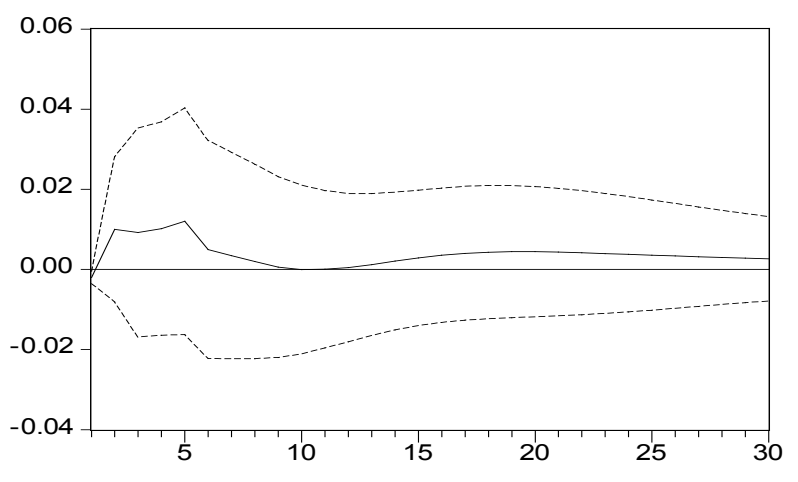

Source: Constructed from the Study Data

Figure 4.13. Impact of privatization on GDP growth rate

Government expenditure policy on privatization seemed to have a positive impact on the economic growth in the short-run as well as in the long-run. This behavior could be explained by the fact that privatization helped to increase competition and efficiency in the market. It also eased the pressure on central government budget and provided short-term revenue to the government for financing development infrastructure. Furthermore, it helped to reduce the government size to an optimal size and in turn budget deficit.

\section{(d) The Impact of Governance on GDP Growth Rate.}

Governance was a dummy capturing the electoral and political processes of the country. It was equal to one in 1992 when Kenya had the first multiparty election, in 2002 when there was a change in government, and in 2007 when coalition government was put in place, and zero otherwise. The impact of one standard deviation shock to governance on economic growth is presented in figure 4.14.

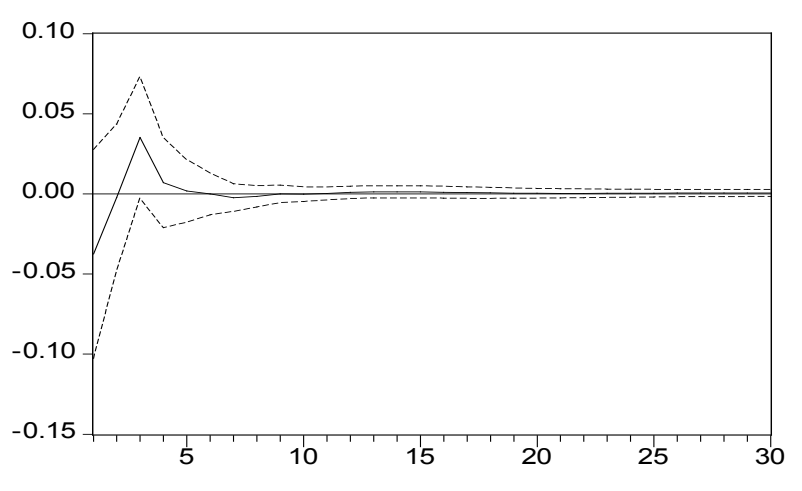

Source: Constructed from the Study Data

Figure 4.14. Impact of governance on GDP growth rate

The response to a one standard deviation shock to governance resulted in a stable time path that moved from an instantaneous negative effect within one year and towards the positive side for a period of four years before fizzling out.

Governance affects economic growth negatively because of uncertainty associated with elections and lack of continuity of government policies when the government regime was changed. It also links government policies with politics which led to rent seeking, corruption and embezzlement of public funds. Because the interest of the special group in general is different from the broad public interest, by accepting money from special interest group, politicians compromise the public interest. This affects the economic growth negatively. The positive effect within the remaining four years could be attributed to return of confidence after an electioneering period, when government policies of the elected government were understood and implemented before another cycle of political campaigns and elections.

\subsection{Variance Decomposition Analysis (VDA)}

The VDA presented a further step of establishing the percentage of the variation in a series that was due to its own shocks and that which was due to shocks of other variables in the model at a given period following Enders (1995) and Stocks and Watson (2001). VDA determined the proportions of a variance in a series that was due to its own shock, the other variable's shocks and other identified institution shocks.

The variations in GDP growth rate brought about by changes in government expenditure components were analyzed. This was an alternative method to impulse response functions for examining the effects of shocks to the GDP growth rate. This technique determined how much of the forecast error variance for any variable in the system was explained by innovations to each explanatory variable over a series of time horizon (Enders, 1995). The own series shocks explained most of the error variance, although the shock also affected other variables in the system. It was also important to consider the ordering of the variables when conducting VDA. This was because in practice the error terms of the equations in VAR were correlated, so that the result depended on the order in which the equations were estimated in the model.

The results of VDA of GDP growth rate are given in the table A7 Appendix V. The results show that most of the variations in GDP growth rate were due to its own shock at 41.036 percent in the first year. The variations of own shocks in economic growth reduced to 28.665 percent in the second year and even to a lower level as the forecasting horizon increased. It was further observed that the variations in the GDP growth rate in the first year was brought about by expenditure components, but the expenditure reforms and governance did not contribute to the variations.

A further observation of the results reveal that the effects of other variables apart from GDP growth rate in the system increased with the increase in forecast period. This implies that GDP growth had feedback effects with variables in the system, and the effects were 
multidirectional. The VDA graphs together with the results in table A 7 in Appendix $\mathrm{V}$ further support the findings of this study that government expenditure components had significant effect on economic growth.

This section reveals that government expenditure components have effects on the economic growth, which lasts for 30 years. The impulse response functions and the VDA have shown that the effects of government expenditure on economic growth are far reaching and they are felt for long periods of time. The effects of public expenditure policy reforms have also far reaching effects on economic growth but their effect is only in the short-run.

The own series shocks explained most of the error variance, although the shocks also affected other variables. The largest proportion of the variance was taken by education, economic affairs, physical infrastructure, investment, health, general administration and budget rationalization. However, their proportions declined over time. Defense expenditure, national security, government consumption, public debts, budget downsizing and outsourcing, privatization and governance did not affect the variance very much within the 30 years.

\section{Summary, Conclusion and Recommendations}

\subsection{Introduction}

This chapter summarizes the study and makes conclusions based on the results. The policy implications from the findings and areas for further research are also presented

\subsection{Summary}

The rapid growth in government expenditure in Kenya has caused concern among policy makers on the implication of such growth, especially to the whole economy in general, and the private sector in particular. Studies have noted that the allocation of financial resources through various policies is neither reflected in the government priorities nor adequately promoted growth in the past. Over the three decades, government expenditure in the country grew at a faster rate than the growth rate of GDP. Given this fiscal scenario, an explanation of this requires studying the impact of government expenditure on economic growth. The specific objectives of the study were to: investigate the relationship between the components of government expenditure and economic growth; examine the effects of components of government expenditure on GDP growth rate; analyze the effects of government expenditure reforms on economic growth; and to draw policy implications from the findings.

It applies Vector Auto Regression (VAR) estimation technique together with annual time series data for the period 1963 to 2008 to evaluate the empirical impact of government expenditure on economic growth. The data used were selected government expenditure components that included government expenditure on government investment, physical infrastructure, education, health care, public debt servicing, economic affairs, general administration and services, defense, public order and national security and government consumption. Data was collected from Kenya government documents such as economic surveys, statistical abstracts, sessional papers and international financial statistics publications.

The study, unlike most other previous studies that used cross-sectional analysis, has used the time-series analysis. Furthermore, unlike the majority of the reviewed literature that used ordinary least squares technique to estimate the relationship between components of government expenditure and economic growth without conducting cointegration and Granger causality test this study used the VAR model. The study unlike most other studies conducted in Kenya examined the effects of government expenditure reforms on economic growth in Kenya. The reforms strategies included budget rationalization, expenditure downsizing and outsourcing, privatization and governance.

The first objective of the study was to investigate the relationship between components of government expenditure and economic growth. The study conducted Johansen cointegration tests for all the variables. The results indicated a long-run relationship between GDP growth rate and government expenditure components.

The study then conducted the Granger causality test between GDP growth rate and the various components of government expenditure. Bidirectional causality between categories of government expenditure and economic growth was detected. The findings support the Keynesian theory, which suggest that increased government expenditure leads to economic growth. The findings also support Wagner hypothesis (1959) that indicates that increased government activity and the corresponding increase in government expenditure is an inevitable result of economic growth due to: increased friction in society causing greater demand for government services; society growing richer therefore requiring the government to provide quality goods and services; and the demand for such goods and services being highly income elastic.

The second objective was to examine the effects of components of government expenditure on economic growth. The VAR employed yielded, impulse response functions and variance decomposition analysis, which revealed that government expenditure on investment, physical infrastructure, education, health, defense, public order and national security, public debt, economic affairs and general administration were important in explaining changes in economic growth. The results showed that government expenditure on physical infrastructure, government investment, economic affairs, health and 
defense had positive impact on the economic growth. However, expenditure on public debt caused economic growth to decline. Furthermore, expenditures on government consumption, education, general administration and public order and national security had mixed impacts on the economic growth.

The third objective was to analyze the impact of government expenditure reforms on economic growth. Four government expenditure reforms were identified and included in the VAR model as dummies for estimation purposes. The study showed that the impacts of budget rationalization, downsizing and outsourcing and privatization on economic growth were positive. Governance had initially a negative effect and then a positive effect on economic growth, which means that during an electioneering period, economic growth declined before it started responding favourably once an elected government was in place and its policies were implemented and understood by the public.

\subsection{Conclusions}

On the basis of the empirical results, the study concludes that the composition of government expenditure matters for economic growth. In the long-run, expenditure on economic affairs, defense, education, government investment, general administration and services and physical infrastructure have positive impacts on economic growth. In the short run health care, public order and national security have positive impact on economic growth, whereas, public debt servicing has negative impact on economic growth.

The government also plays a leading role in determining the pattern of economic growth through public expenditure reforms, which determine directly how much of an economy's resources to divert to its own use and how those resources should be allocated in order to increase economic growth. The results reveal that government expenditure reform on privatization should be given priority for a government interested in promoting long-run growth. Budget rationalization, governance and downsizing and outsourcing appear to be appropriate policies for increasing economic growth in the short-run. Therefore, the results of this study emphasize the fact that the composition of government expenditure and public expenditure reforms are important in determining economic growth.

\subsection{Policy Implications}

Several policy implications can be drawn from the research findings.

The government should increase its investment in areas that are beneficial to the private sector and eschew from those that compete with or crowd it out. It should Increase its expenditures on those items that enter private production functions as productive public inputs that enhances economic growth. Such productive government investment expenditure includes expenditure on buildings, plant, machinery and equipment all of which generate positive externalities that raise private investment and thus economic growth.

The government should allocate more resources to areas of physical infrastructural development in order to stimulate economic growth as envisaged in the vision 2030. This is because additional expenditure on physical infrastructure in such areas as roads, railways, ports, communication, water and electricity contribute significantly to the economic growth by increasing the marginal productivity of inputs in the private and public sectors. Furthermore high government expenditure on transportation and communication and energy create an enabling environment for business to thrive through reduced cost of production.

The government should increase it its expenditure allocation to the education and human capital development. This could be done through provision of proper education facilities such as schools colleges and universities, training and employing more teachers, ensuring access to education to all citizens, reduction of the cost burden to the parents/guardian and expanding education to the marginalized groups. This is because quality education creates positive externalities and increases the productive capacity that helps to raise the steady state rate of economic growth.

The government should allocate more funds for the development of the health care sector. This should be achieved through investment in proper capital equipments, health facilities and provision of quality medical supplies. The government should also consider human capital investment through training of the human resources relevant to this sector such as doctors and nurses. This is because, when there was an increase in expenditure allocation to the health care sector, the level of economic growth increased since a health nation is a wealth nation.

The government should streamline its allocation to the debt servicing. This is because public debt servicing reduces the resources that could otherwise have been allocated to more productive sectors of the economy. Furthermore, public debt servicing crowd out private investment which affect economic growth adversely. The reduction in public debt can be achieved by reducing government borrowing and ensuring that borrowed loans are concessional in nature. This means that since the government would have a long repayment period at a lower interest rate, the burden on public debt would be lesser.

The allocation to economic affairs should be increased by the government. This would be achieved by ensuring that the sectors that are productive in nature under this allocation are accorded the right attention while those that are non-productive in nature are rationalized. This is because economic affairs provide a direct provision of productive activities thorough its expenditure in areas of 
maintenance and operations, agriculture, manufacturing, trade, mining, fisheries, forestry, tourism and construction.

The government should streamline its expenditure allocation to the general administration and services and also increase its efficiency in service delivery. This would go a long way in saving funds that could be used in other priority sectors. This implies that the government should have sustainable policies for development to avoid crowding out the private investors who play a vital role to the growth and development of the economy. The efficiency in government sector could also lead to improved efficiency in the markets for goods and services, factor market and financial asset markets that help to mobilize resources for private investment.

The government should increase its expenditure allocation to defense and public order and national security. This is because, when the allocation to these sectors is increased, there is a positive change in economic growth. These sectors help to improve security within the economy thereby increasing economic activities in areas of tourism and private investment. In addition the sectors help to increase competition in the economy due to increased protection and enforcement of government legal structure.

Effort should be made by the government to reduce its consumption. This is because increased government consumption crowds out private investments and reduces the disposable income of the people which result to reduced household consumption in the economy.

The government should restructure government expenditure through budget rationalization in order to achieve an effective public sector. It is important for policy makers to pay attention not just to the levels of government expenditure, but also to its composition. Besides, prioritization of government expenditure should be judged not only by virtue of its economic returns, but also on the technical, administrative and financial feasibility front. Proper measure of cost and benefits of various government expenditures is essential in this respect. A clear set of specified criteria for deciding the allocations of resources should be followed to avoid arbitrary allocation and rent seeking by promoting transparency and accountability. This requires long-term programmes of budget rationalization focusing on elimination of wasteful and unproductive expenditure thus improving equity through distributional impacts and maximizing economic growth by ensuring that fiscal operations are conducted in the least cost manner.

In order to reduce the rate of growth of expenditure on salaries and allowances, the government should streamline its civil service to the minimum by freezing recruitments and increasing wage in line with the economic growth. The government should also adopt the advanced technologies in its service delivery in order to cut down the size of civil service. This is because reduced civil service helps in the diversion of resources from unproductive expenditure on wages and salaries, to a more productive expenditure in form of infrastructure and education.

The government should reduce its size to an optimal one by adopting a policy on privatization and expenditure downsizing and outsourcing to cut its expenditure and in turn ease public debt. This is because running a large public debt for a long-period of time could have an adverse effect on the economic growth since borrowing might crowd out private sector investment.

Donors and development partners should partner with government in creating a platform for investment and development and support the initiatives spearheaded by the government. Regional integration should be explored to ensure that gains that could be obtained regionally such as trade and industrialization are maximized,

The private sector should partner with government in provision of certain services through Public-Private Partnership (PPP). This could be achieved through joint efforts in provision of services such as infrastructure, energy, health and education.

Individuals on the other hand should be responsible citizens, hardworking and business minded by engaging in entrepreneurial ventures. This should be done by people in all walks of life to ensure a cohesive and prosperous nation

\subsection{Limitations and Areas for Further Research}

First, the practical implication of VAR model is that the number of variables should be minimal and plausibly related to each other so that they can be useful in forecasting each other. The study assumed no tax and the results could be different if the assumption was relaxed.

It is also important to mention that the government may have other objectives other than promoting economic growth for example, inducing some redistribution of income, which are not visible in national accounts figures, and that certainly explains a partially the government expenditure behavior on economic growth.

In future work, it would be important to extend the sample size to test for the robustness of the results.

In view of political challenges such as the demographic burden and climatic change, it becomes increasingly important to explore further what portfolio of government outlays is optimal in economic growth and welfare terms.

Future research should be devoted to the complex transmission channel leading from government expenditure to economic growth.

Finally, although the focus of this study is solely on measuring the impact of government expenditure on economic growth, an important issue to address in future research is what determines government decision to allocate expenditure among various components. In particular, the role of demographic factors and the nature of the political process. 


\section{REFERENCES}

[1] Ahmed, H. (1999). Crowding-out and Crowding in Effects of the Components of Government Expenditure. New York: Harper Publishers.

[2] Ag'enor, P.R., and Moreno, D. (2007). Public infrastructure and growth: New channels and policy implications in public expenditure. Edited by Maura Francese, Daniele Franco, and Raffaela Giordano, Banca d'Italia and World Bank working Paper.

[3] Age'nor, P.R. (2007). The Economic Adjustment and Growth. New Delhi: Viva books Private Limited.

[4] Aschauer, D. (1989). Is government spending productive? Journal f Monetary Economics, 23, 177-200.

[5] Bailey, S.J. (2002).Causes of government expenditure growth: A survey of the U.S evidence. Journal of Public Economics, 28, 359-82.

[6] Barro, R.J. (1990). Government spending in a simple model of endogenous Growth. Journal of Political Economy, 98, 103-25.

[7] Barro, R. J. (1991). Economic growth in a cross-section of countries. Quarterly Journal of Economics, 106, 407-443.

[8] Barro, R.J., and Sala-i-Martin, X. (1992). Public finance in models of economic growth. Review of Economic Studies, 59, 645-661.

[9] Barro, R.J., and Sala-i-Martin, X. (2007). Economic growth. New Delhi: Viva books private limited.

[10] Barro, R.J., and Sala-i-Martin, X. (1995). Economic Growth. New Delhi: McGraw-Hill.

[11] Bils, M., and Kienow, P.J. (1998). Does schooling cause growth or the other way around?, Working Paper 6393, National Bureau of Economic Research.

[12] Bleaney, M., Gemmell, N., and Kneller, R. (2000). Testing the endogenous growth model: Public expenditure, taxation and growth over the long- run. Discussion paper, 00/25, University of Nottingham.

[13] Branson, W. H. (1989). Macroeconomic Theory and Policy. New York: Harper Publishers.

[14] Brown, C. V., and Jackson, P. M. (1996). Public sector Economics. (4th Ed) Oxford: Blackwell Publishers.

[15] Brunner, K., and Meltzer, A. H. (1992).Money and the Economy: Issues in Monetary Analysis. University of Rocheste: Bradley policy Research Center press.

[16] Burda, M., and Wyplosz,. C. (2001). Macroeconomic of European Countries. (3rd Ed). New York,: Oxford University press.

[17] Canning, D., and Fay,. M .(1995). Infrastructure and Growth. Mimeo: Brookings Publishers.

[18] Caselli, Esquivel and Lefort,. (1996). Reopening the convergence debate: A new look at cross-country growth empirics, Journal of Economic Growth, 1, 363-90

[19] Cashin, P. (1995). Government spending, taxes and economic growth. International Monetary Fund, 42,
237-269.

[20] Chang, B.S., and Lai, T.W. (1997). Government expenditure and economic growth in South Korea: A VAR approach. Journal of Economic Development, 22, 11-24.

[21] Colombier, C. (2000). Does the Composition of Public Expenditure Affect Economic Growth. Ph.d Thesis, Switzerland: Unpublished.

[22] Cullison, W.E. (1993). Public investment and economic growth. Federal reserve Bank of Richmond. Economic Quarterly, 79, 19-23.

[23] De la Fuente, A. (1997). Fiscal policy and growth in the OECD. CEPR Discussion paper 1755.

[24] Devarajan, S., Swaroop, V., and Heng-fu, Z. (1993). What do government buy?: The composition of public spending and economic performance. Policy Research working paper 1082 .

[25] Devarajan, S., Swaroop, V., and Heng-fu, Z. (1996). The composition of Public expenditure and economic growth. Journal of Monetary Economics, 37, 313-44.

[26] Devarajan, D., Swaroop, V., and Hengful, Z.(1993).What the government buy?: The composition of public spending and economic performance. World Bank working papers 1082 .

[27] Diamond, J. (1989). Government expenditure and economic growth: An Empirical investigation. IMF working paper $89 / 45$.

[28] Dowrick, S. (1993). Estimation the Impact of Government Consumption on Growth: Growth Accounting and Optimizing Models. Canberra: Australian National University press.

[29] Dunne, P., and Nikolaidou, E. (1999). Military expenditure and economic growth: A demand and supply model for Greece, 1960-1996. Discussion Paper Series in Economics, 62.

[30] Easterly, W. and Robelo, S. (1993). Fiscal policy and economic growth: An empirical investigation. Journal of Monetary Economics, 32, 417-458.

[31] Easterly, Loayza, and Montiel, P.J. (1997). Has Latin America's post-reform growth been disappointing?. Journal of International Economics, 43, 287-311.

[32] Engle, R.F., and Granger, C.W.J.(1987). Cointegration and error correction: Representation, estimation and testing. Econometrica, 55, 251-276.

[33] Enders, W. (1995). Applied Econometric Time-Series. New York: John Wiley and Sons Inc.

[34] Feder, G. (1983). On exports and economic growth. Journal of Development Economics, 12, 59-73.

[35] Folster, S., and Henrekson, M. (1997). Growth and the public sector's critique of the critics. The research institute of industrial economics. Working Paper. 492.

[36] Frideriksen, P., and Looney, R. (1982). Defense expenditure and economic growth in developing countries: some further empirical evidence. Journal of Economic Development, 7, 113-125. 
[37] Friedman, M. (1956). A Theory of the Quantity of Money. Princeton New Jersey: Princeton university press.

[38] Ghali, K. H. (1999). Government size and economic growth: Evidence from a multivariate coitegration analysis. Applied economics, 31, 975-987.

[39] Grier, K., and Tullock, G. (1989). An empirical analysis of cross-national econometric growth 1959-80 .Journal of monetary Economics, 24, 259-276.

[40] Hanson, P., and Henrekson, M. (1994). A new framework for testing the effect of government spending on growth and productivity. Public Choice, 81, 381-401.

[41] Hsieh, E., and Lai, K. (1994). Government spending and economic growth. Applied Economics, 26, 535-42.

[42] Johansen, S. (1988). Statistical Analysis of cointegration vectors. Journal of Economic Dynamics and Control, 12, 231-54.

[43] Johansen, S. (1995). Likelihood-Based Inference in Cointegrated Vector Autoregressive Models. New York: Oxford University press.

[44] Kalyoncu, H., and Yucel, F. (2006). An analytical approach on defence expenditure and economic growth; the case of Turkey and Greece, Journal of Economic Studies, 33(5), 336-343.

[45] Keynes, J., M. (1936). The General Theory of Employment, Interest and Money. New York: Oxford University Press.

[46] Khan, M.S., and Kumar, M.S. (1997). Public and private investment and the growth process in developing countries. Oxford Bulletin of Economics and Statistics, 59, 69-88

[47] King, R. G., and Robelo, S. (1990). Public Policy and endogenous growth: Developing neoclassical implication. Journal of Political Economy, 98, 126-50.

[48] Kneller, R., Bleaney, M.F., and Gemmell, N. (1999). Fiscal policy and growth: Evidence from OECD countries. Journal of Public Economics, 74:171-190.

[49] Kneller, R. (1999). Public expenditure and economic growth: A disaggregated analysis. Journal of Public economics 73, $170-200$.

[50] Knight et al. (1996). The Peace divided: military spending and economic growth: IMF staff papers 43(1). Washington D.C

[51] Kocherlakota, N.R., and K-M, Y. (1997). Is there endogenous long-term growth?: Evidence from the United States and the United Kingdom. Journal of Monetary, Credit, and Banking, 29, 235-62.

[52] Kosimbei, G. (2009). Budget deficits and macroeconomic performance in Kenya (1963-2007): An empirical analysis. Ph.D Thesis, Kenyatta University: Unpublished.

[53] Koori, C. G. (1984). The existence and nature of the crowding out effect in Kenya. MA Thesis, University of Nairobi: Unpublished.

[54] Kweka, J. P. (1995). Public spending and economic performance in Tanzania: An empirical investigation 1970-1993. MA Thesis, University of Dar es Salaam: Unpublished.
[55] Lin, S. (1994). Government spending and economic Growth. Applied Economics, 26, 83-94.

[56] Landau, D. L. (1985). Government expenditure and economic growth in the developed countries $1952-1976$. Public Choice. 47, 459 - 447.

[57] Landau, D. (1983). Government expenditure and economic growth: A cross-section study. Southern Economic Journal. $48,450-478$.

[58] Landau, L. (1985). Sensitivity analysis of cross-country growth regressions. American Economic Review, 82, $942-$ 943

[59] Landau, L. (1986). Government and economic growth in the less developed countries: An empirical study for 1960-88. Economic Development and Cultural Change, 35, 35-75.

[60] M'Amanja, D., and Morrissey, O. (2005). Fiscal policy and economic growth in Kenya. Credit Research Paper, 05/06.

[61] Mackenzie, G. A, Orsmond, D.W., and Gerson P.R. (1997). The composition of fiscal adjustment and growth lesions from fiscal reforms in eight economies. IMF Occasional Paper 149. IMF Washington. D.C.

[62] McCoy, D. (1997). How useful is structural VAR analysis for Irish economy? Paper presented at an international seminar of the central Bank of Ireland.

[63] Milbourne, Otto, R.G, and Voss. G. (2003). Public investment and economic growth, Journal of Applied Economics, 35, 527-40.

[64] Moshi, H., and Kilindo, A. (1994). The Impact of growth policy on Macroeconomic variables: The case of private investment in Tanzania. Paper submitted to the AERC, Nairobi, Kenya, December.

[65] Myles, S. D., and Hindriks, J. (2007). Intermediate Public Economics. India: Asoke K. Ghosh Publishers.

[66] Musgrave, R .A., and Musgrave, P. B. (1989). The Theory of Public Finance. New York: McGraw-Hill.

[67] Nelson, M.A., and Sing, R.D. (1994). The deficit-growth connection: Some Recent Development and Cultural change, $43,167-91$

[68] Njuguna, N.J. (2009a). Government expenditure and economic growth in Kenya: An empirical analysis 1963-2006. MA. Thesis. Kenyatta University: Unpublished.

[69] Njuguna, A.E. (2009b). Growth and convergence in a disequilibrium Solow-Swan model: The case of ASEAN countries 1960 to 1995 . Ph.D. Thesis, University of New England: Unpublished.

[70] Peacock, A., and Wiseman, J. (1961).The Growth of Public Expenditure in The U.K. London: Princeton University press.

[71] Peperron, P. (1998). The great crash, the oil price shock, and the unit root hypothesis. Econometrics Research program Paper 338. Princeton

[72] Peperron, P. (1989). The great crash, the oil prices Shock and the unit root hypothesis. Econometrica, 57, 1361-1401.

[73] Peter, S. (2003). Government expenditure effect on 
economic growth: The case of Sweden, 1960-2001. A Bachelor thesis submitted to the department of business administration and social sciences, Lalea University of technology, Sweden.

[74] Ram, R. (1986). Government size and economic growth: A new framework and some evidence from cross-section and time-series. American Economic review, 76, 191-203.

[75] Ranjan, S.C. (2008). "Government expenditure and economic growth: Evidence from India. The ICFAI University Journal of Public Finance, 6, 60-69.

[76] Republic of Kenya. (1965). Sessional Paper No. 10 of 1965: African Socialism and its Application to Planning in Kenya. Nairobi: Government Printers.

[77] Republic of Kenya .(1986). Sessional Paper No. 1 of 1986: Economic Management for Renewed Growth. Nairobi: Government Printers.

[78] Republic of Kenya. (1997). National Development Plan 1997 - 2000. Nairobi: Government Printers.

[79] Republic of Kenya. (2006). Annual Progress Report 2004 2005, Economic Recovery Strategy. Nairobi: Government Printers.

[80] Republic of Kenya. (2007). Kenya Vision 2030: A Globally Competitive and Prosperous Kenya. Nairobi: Government Printers.

[81] Republic of Kenya. (Various issues). Economic Survey. Nairobi: Government Printer.

[82] Republic of Kenya. (Various issues). Statistical Abstracts. Nairobi: Government printer.

[83] Republic of Kenya .(Various issues). Budget Speech. Nairobi: Government Printer.

[84] Republic of Kenya. (Various issues). Public Expenditure
Review. Nairobi: Government Printer.

[85] Romer, P. M. (1990). Endogenous technologies change. Journal of Political Economy, 98, 71-102.

[86] Sims, C. (1980). Macroeconomics and reality. Econometrica, $48,1-48$.

[87] Singh,. R. J., and Weber, R. (1997). The composition of public expenditure and economic growth: Can anything be learned from Swiss data?. Swiss Journal of Economic and Statistics, 133, 617-634.

[88] Solow-Swan, R. (1956). A contribution to the theory of economic growth. Quarterly Journal of Economics. 50, $65-94$

[89] Stiglitz, J. E. (1989). The Economic Role of the State. Heertze: Oxford University Press.

[90] Stock, J. (1994). Unit roots, structural breaks and trends. Handbook of Econometrics, 4, 2739-2841.

[91] Stock, J.H., and Watson, M. W. (2001). Vector Auto regressions. Journal of Economic Perspectives, 15, 101-115.

[92] Tanninen, H. (1999). Income inequality, government expenditure and growth. Applied Economics, 31, 1109-1117.

[93] Trotman. D. T. (1997). Economics of the Public Sector. London: Macmillan Press.

[94] Tsay, R. (2001). Analysis of Financial Time-Series. New York. John Wiley and Sons.

[95] Watson, M.W. (2001). "Vector auto regressions." Journal of Econometric Perspectives". 15, 101-115.

[96] Wawire, N.H.W. (2006). The determinants of tax revenue in Kenya. Ph.D. Thesis, Nairobi, Kenyatta University: Unpublished. 